تجزيه و تحليل مكانى تكهتكهشدگى جنگلهاى زاگرس مركزى براى مقاصد حفاظت و احياى اراضى (مطالعه موردى: جنگلهاى يشتكوه فريدونشهر، استان اصفهان)

\author{
مزّده صفائى'، رضا جعفرى "* و حسين بشرى'
}

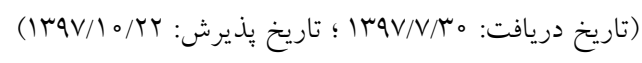

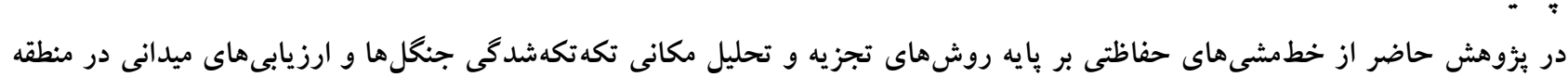

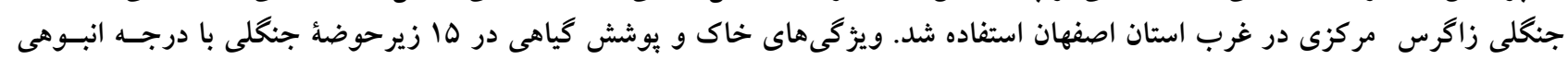

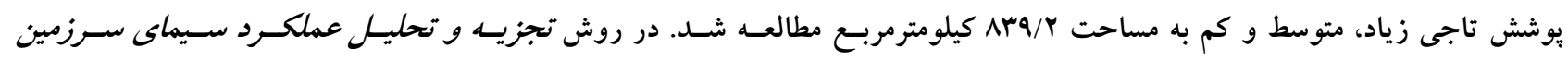
(LFA) Landscape Function Analysis

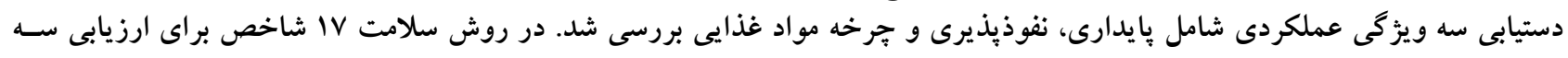

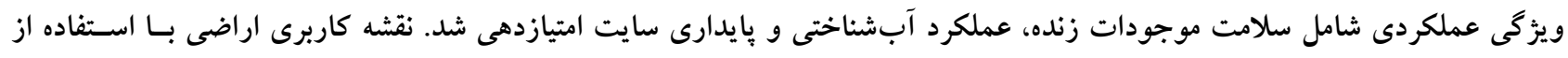

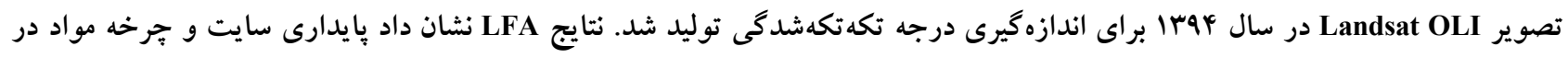

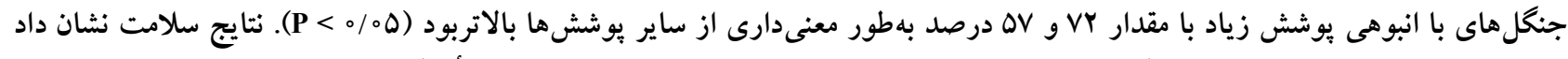

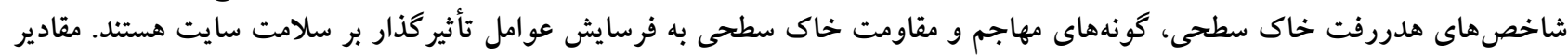

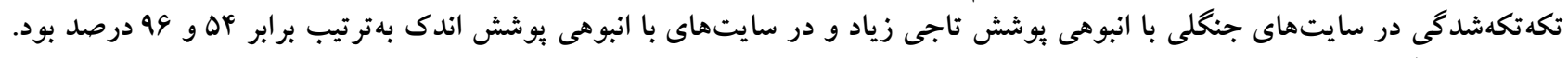

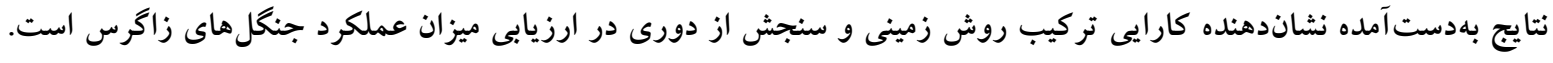

وازمهاى كليدى: سلامت اكوسيستم، تحليل عملكرد سيماى سرزمين، شاخصهاى ساختارى و عملكردى 


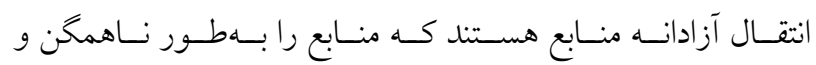

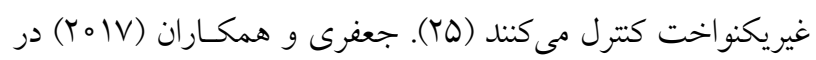

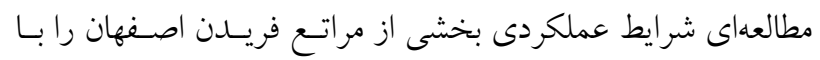

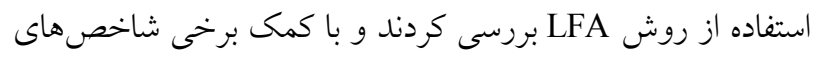

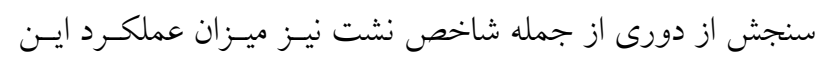

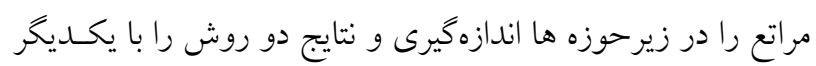

مقايسه كردند (11).

با مطالعه توانمندى و يتانسيل هر اكوسيستم جنكلى كـه متـأثر

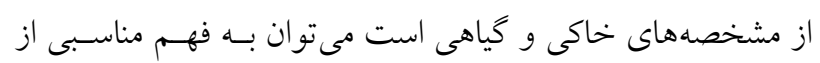

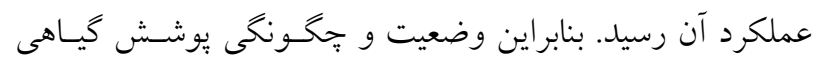

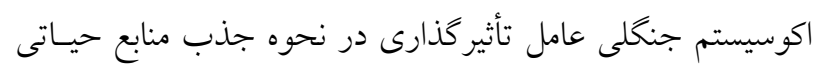

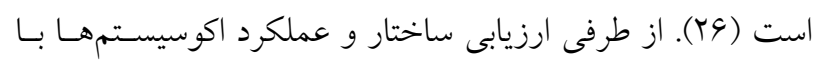

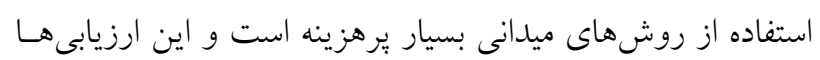

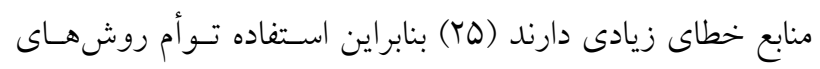

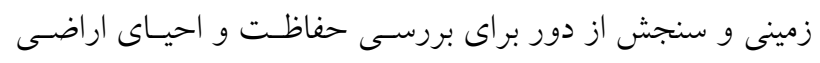

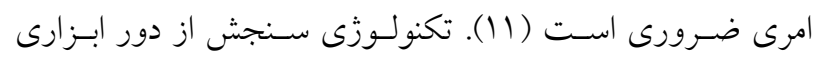

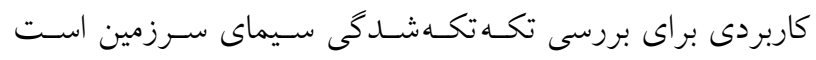

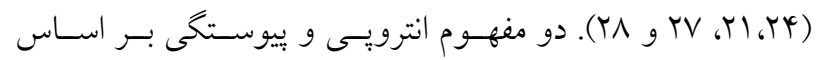

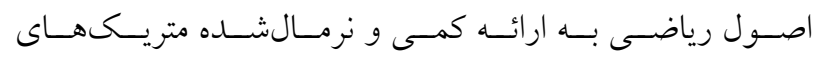

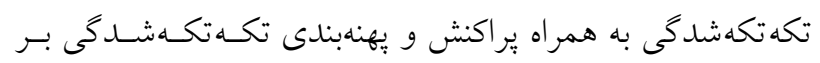

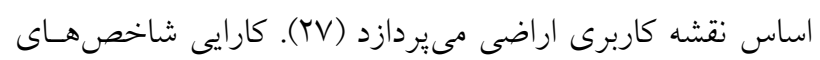

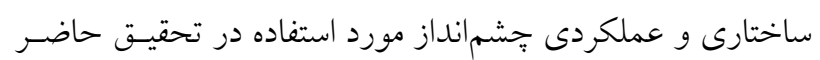

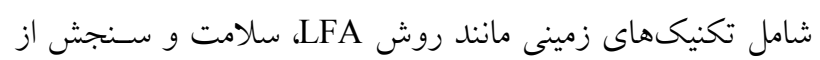

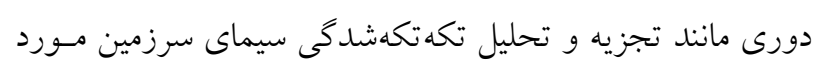

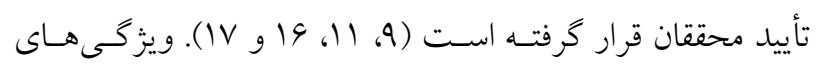
يوشـش اراضسى در تصـاوير رسترى اغلـب بـهـوسـيله الكوهـا،

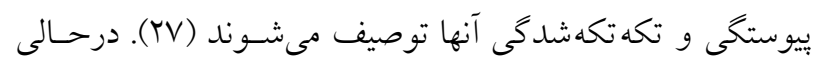

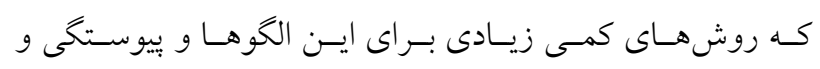

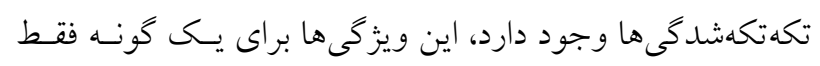

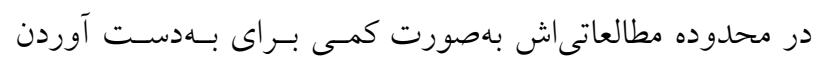

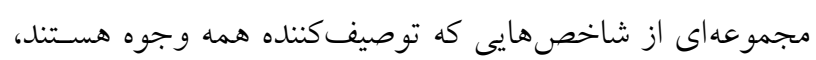

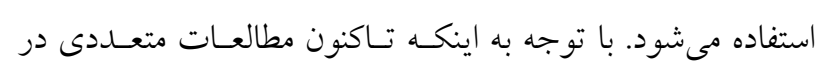

بروز آشفتخى هـاى كونـاكون در اكوسيستمهــا منجـر بــه تغييـرات

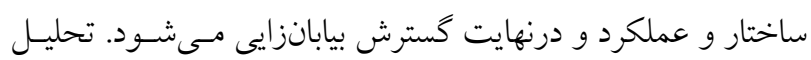

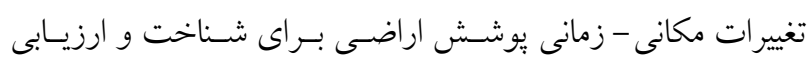

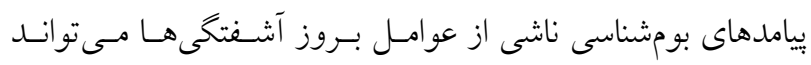

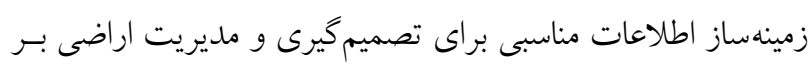

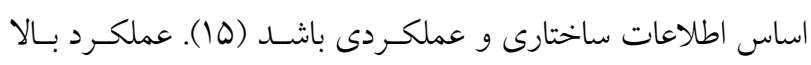

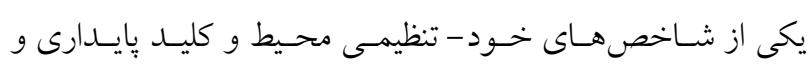

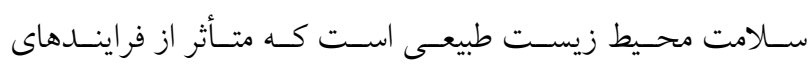
بومشناختى، آبشناختى و بِ خسوردها و واكنشهاى ايسن فراينـدها

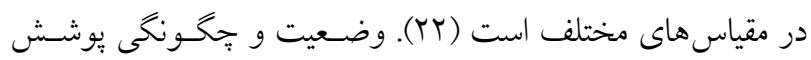

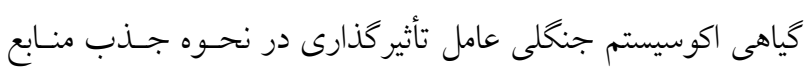

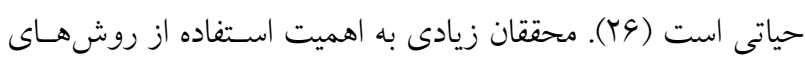

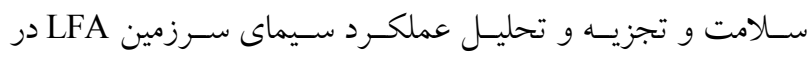

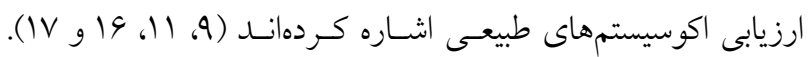

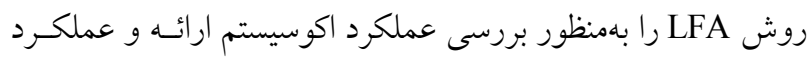

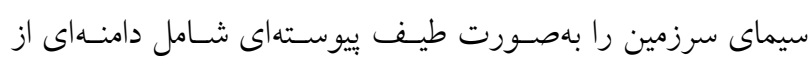
عملكرد كامل تا سوءعملكرد كامل معرفى شد (Y)). ايسن روش در

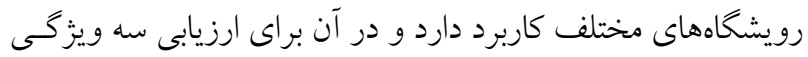

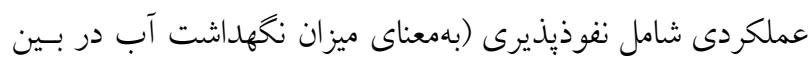

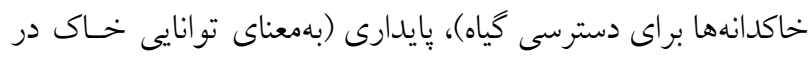

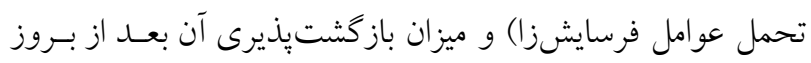

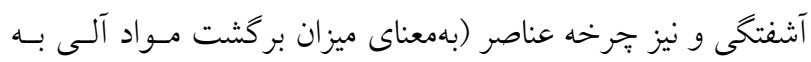

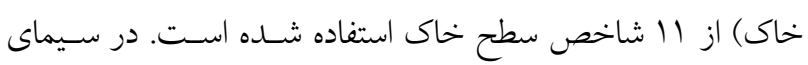

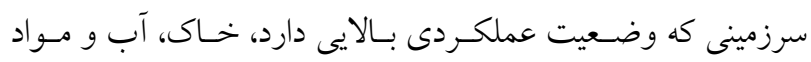

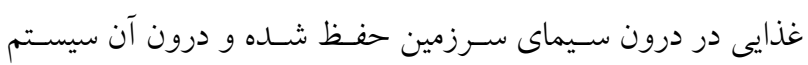

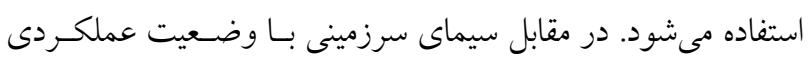

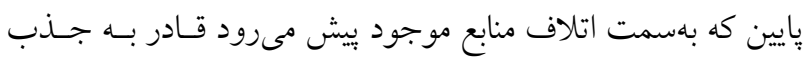

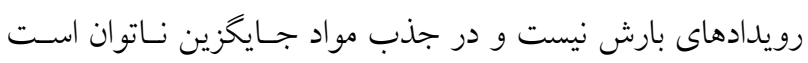

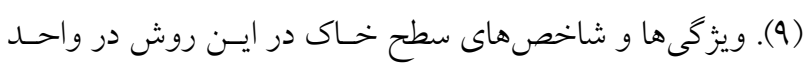

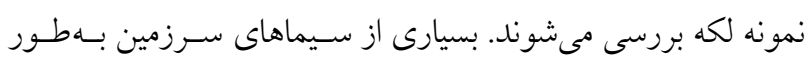

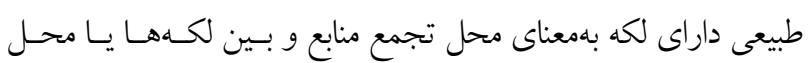


تا ها درصد است. بر اسـاس آمـار و اطلاعـات ارائسه شـده توسط اداره منابع طبيعى شهرستان فريدونشهر، در محسدوده استه منطقه مورد مطالعه FY990 واحد دامى وجود دارد كه حدود

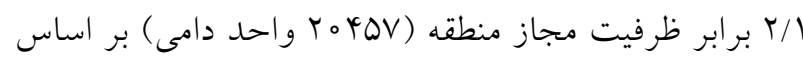
يروانهاى جرايى موجود است.

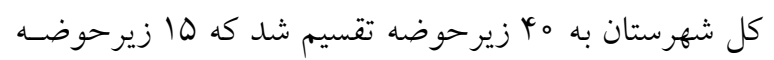

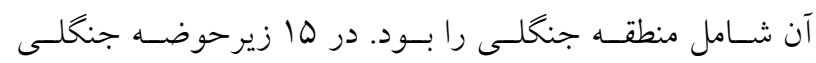

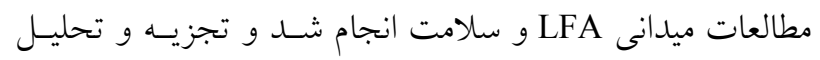

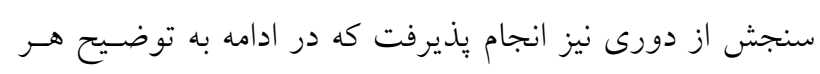
روش برداخته شده است.

\section{تقسيمبندى سايتهاى جنگلى}

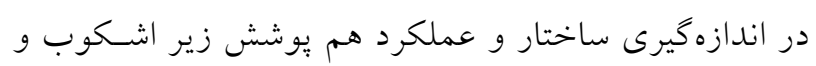
هم بوششتاجى مهم است؛ گونه غالب سايتهاى مطالعـاتى را درختان بلوط غرب Quercus brantii Lindl تشـكيل داده است و از روش قدم نقطه براى تعيين درصد يوشش بـ استفاده

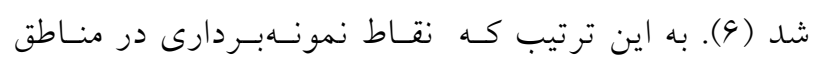

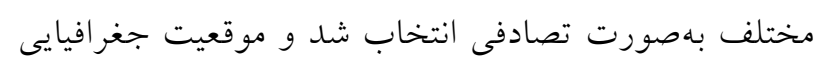

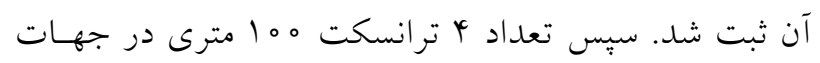

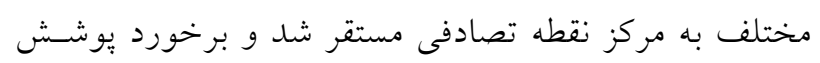

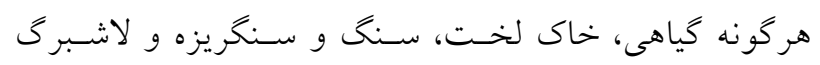

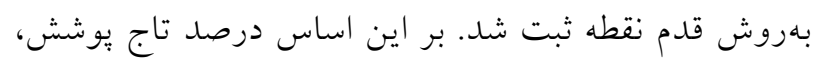

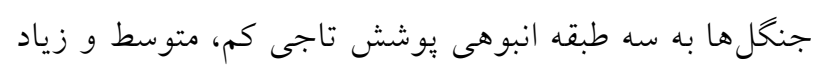

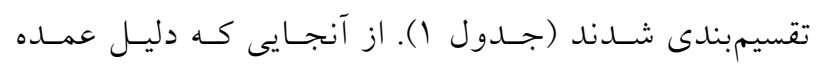

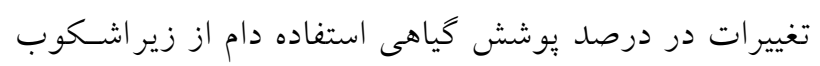

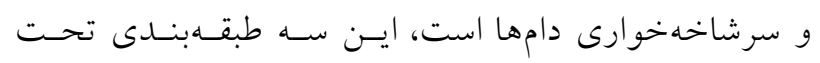

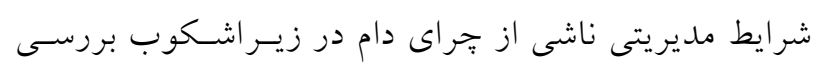

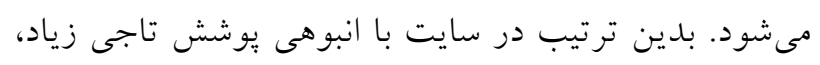

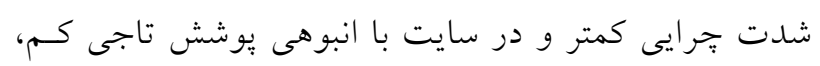

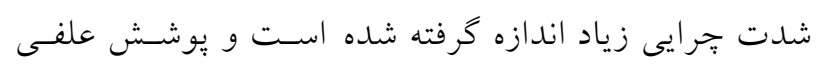

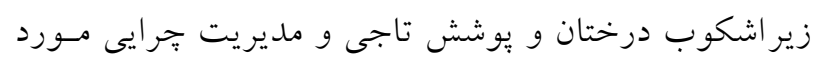
بر برسى قرار خرفت.
زمينه اندازهيرى و ارزيابى شاخص هاى ساختارى و عملكردى و

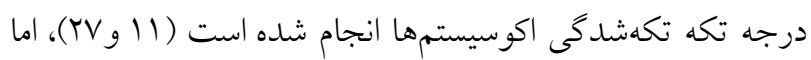

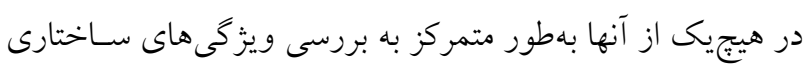

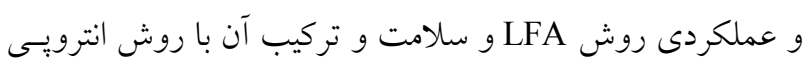

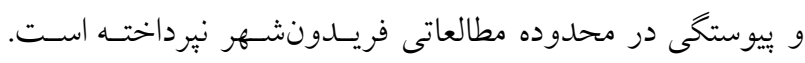

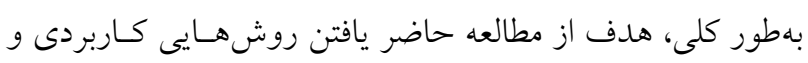

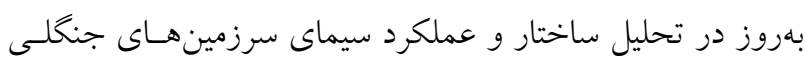

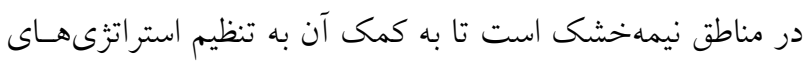

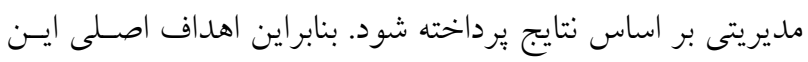

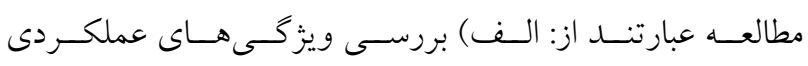

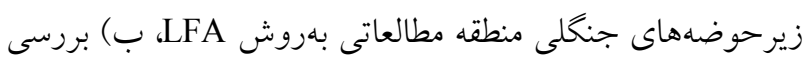

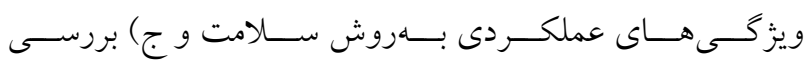
تكهتكهشدكى سايتهاى مطالعاتى بـهروش انترويسى (Entropy ) وييوستخى (Contagion)

\section{مواد و روشها - - ماد منطقه مورد مطالعه} منطقه مورد مطالعه در شهرسـتان فريـدونشهـهر و در فاصـله

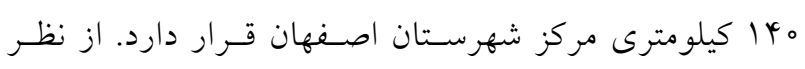

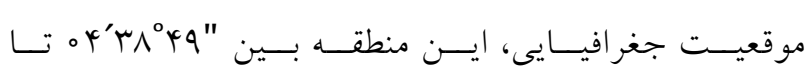
"

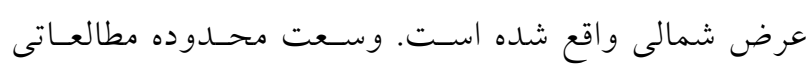

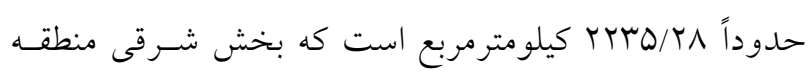

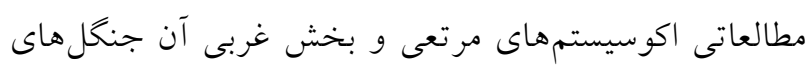

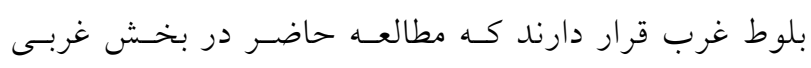
شهرستان انجام شده است (شكل (1). متوسط بـ بـارش منطقـهـ

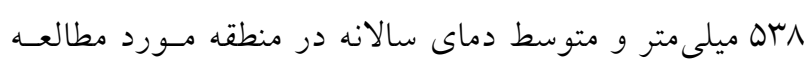

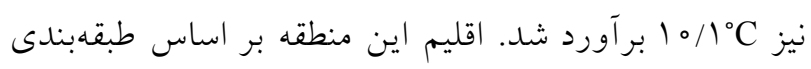

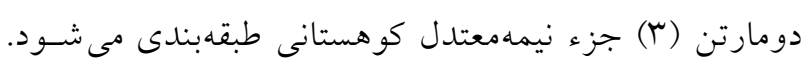

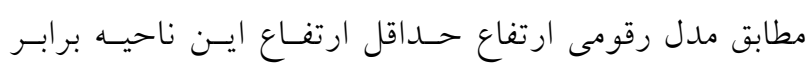

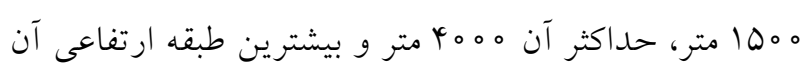

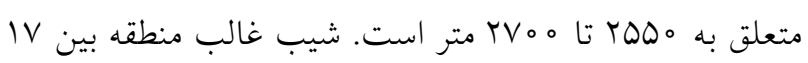




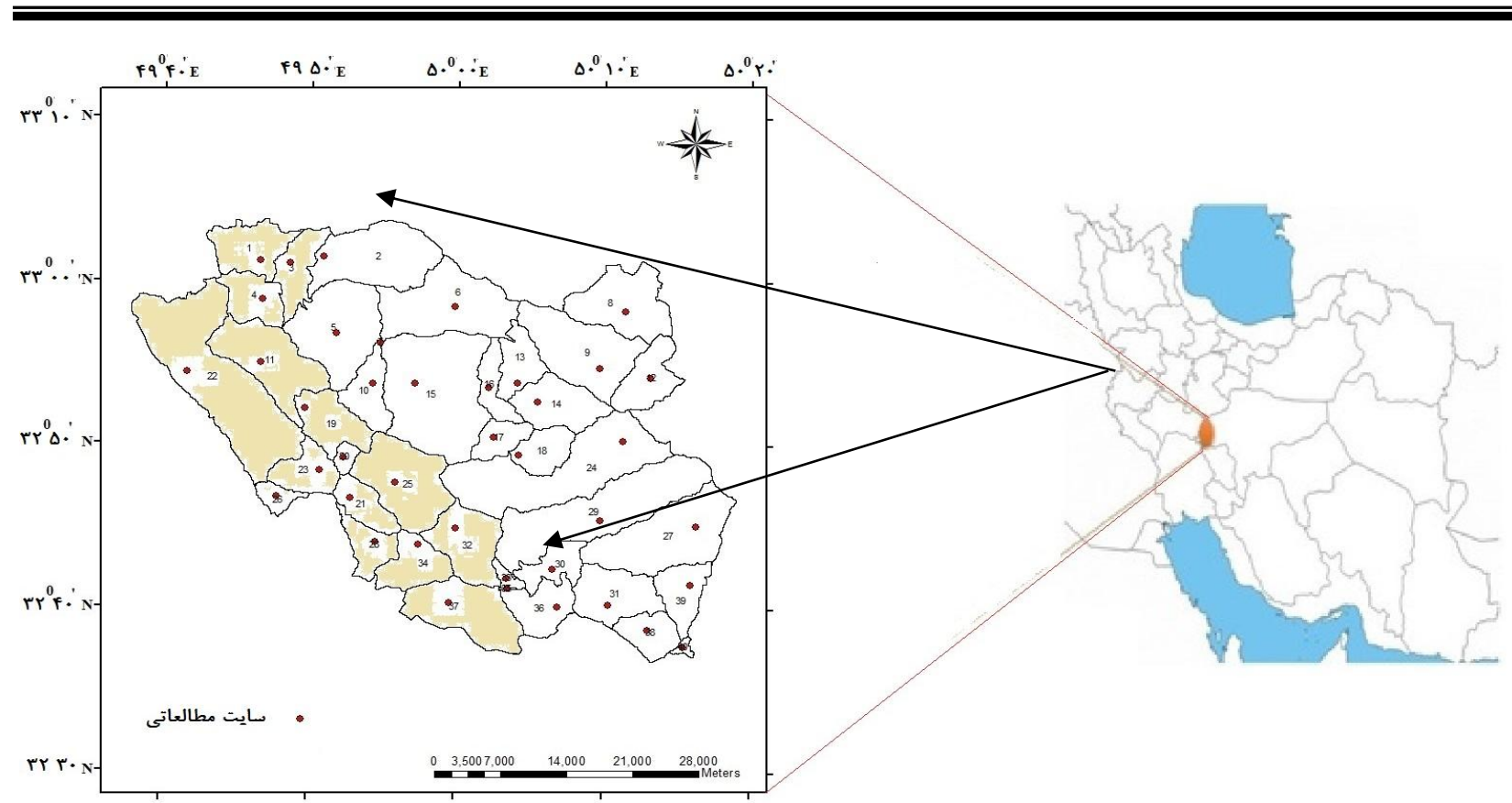

شكل ا. منطقه مطالعاتى در غرب استان اصفهان (زيرحوضههاى جنگلى مورد مطالعه به رنغ كرمى در نقشه مشخص شدهاند. تصاوير

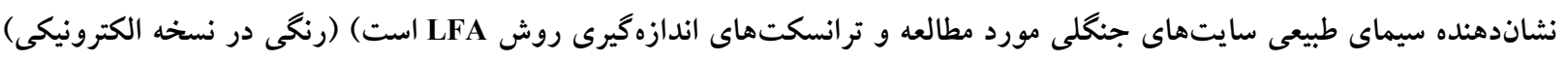

جدول ا. طبقهبندى انبوهى يوشش تاجى جنغلهاى بلوط زاكرس (rq) و مديريت جرايى بررسى شده در منطقه مطالعاتى

\begin{tabular}{|c|c|c|}
\hline شدت تجرا & طبقدبندى انبوهى يوشش تاجى در جنگكل هاى زاكرس & درصد تاج يوشش \\
\hline زياد & تاج يوشش با انبوهى كم & ا Tا-ه درصد \\
\hline 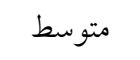 & تاج يوشش با انبوهى متوسط & | ا م- ا درصد \\
\hline كم & تاج يوشش با انبوهى زياد & T T مرصد و بيشتر \\
\hline
\end{tabular}

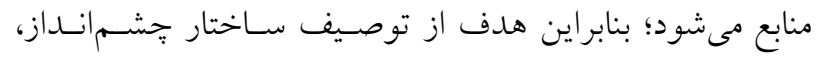

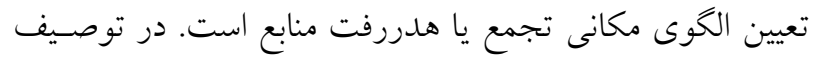

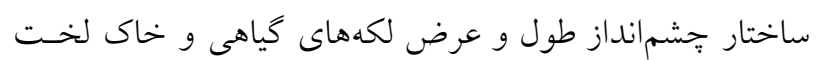

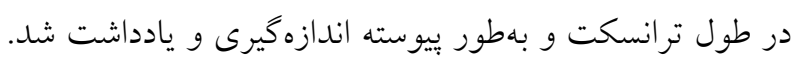

LFA اندازهگيرى ساختار بهروش در هر يكى از ها زيرحوضه مطالعاتى يكى منطقه كه معرف كـل سلـ

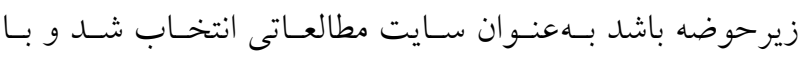

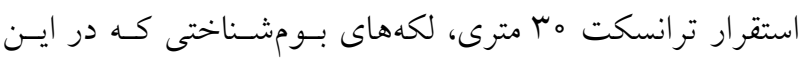
روش بهعنوان محل تجمع منابع درنظر كرفته مى شـوند (منظـور

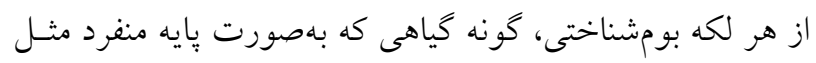

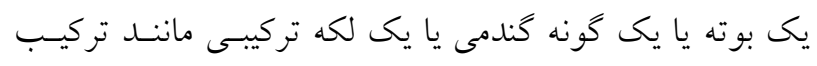

روش تحليل عملكرد سيماى سرزمين (LFA)

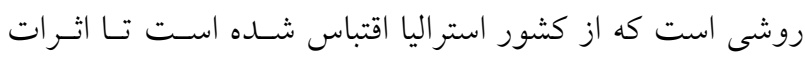

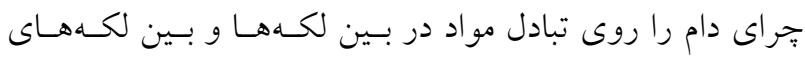

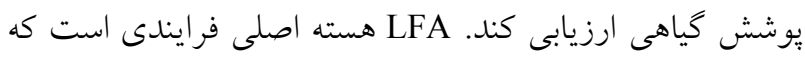

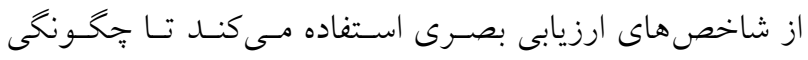

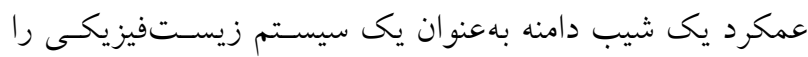
بسنجد. ساختار هر جشمانداز از لكههاى يوشش كياهى و خاك لخت تشكيل شده است؛ ولى نسبت، اندازه، فراوانى و يـراكنش لكههاى يوشش كيـاهى در جشـــانـازهاى مختلـف، متفـاوت است. لكههاى يوشش كياهى سبب تجمع منابع درون جشمبانداز

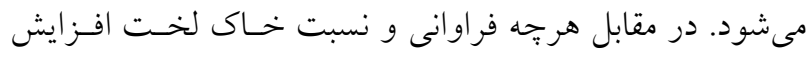

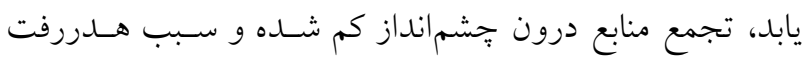


سيماى سرزمين در سه مشخصه اصلى شامل ويايدارى، نفوذيذيرى

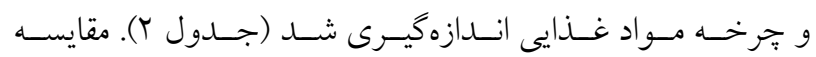

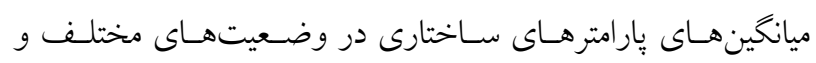

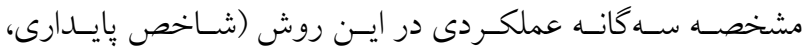

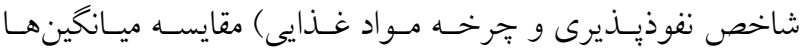

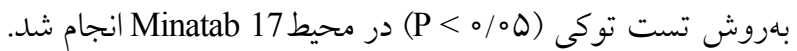

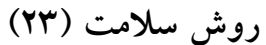

عمليات ميدانى براى تعيين شاخصهاى مهم و تأثير خذار مدل

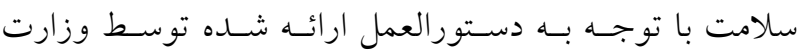

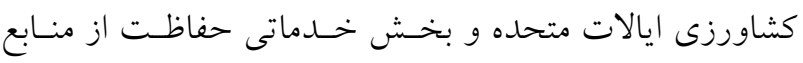

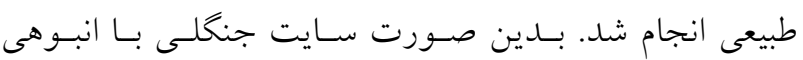

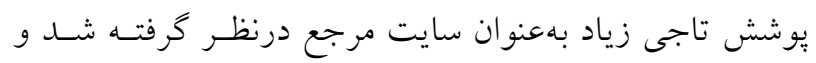

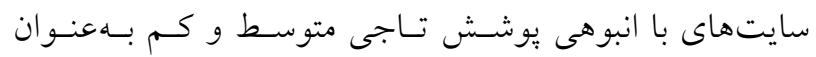

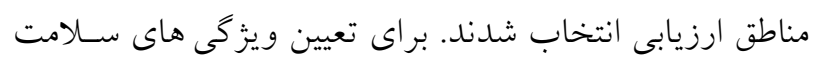

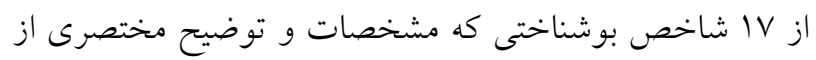

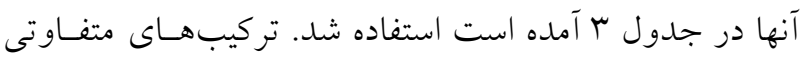

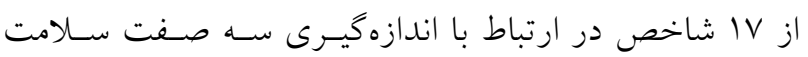

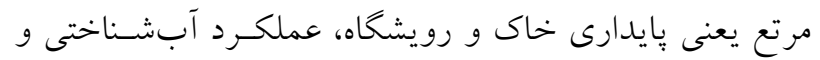

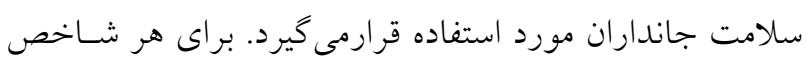

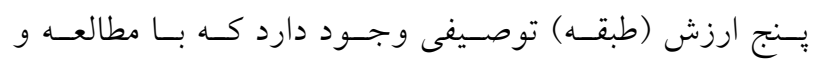

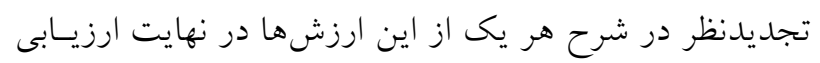

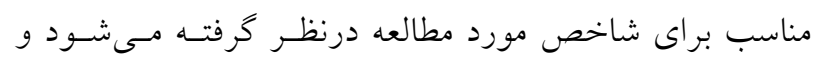

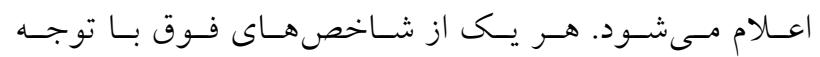

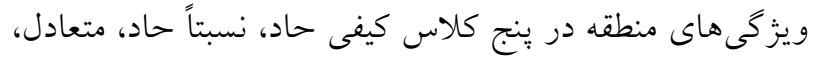

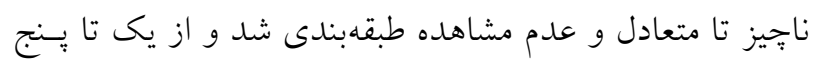
امتيازبندى شد. باتوجه به كيفى بودن شـاخصهـاى سـلامت،

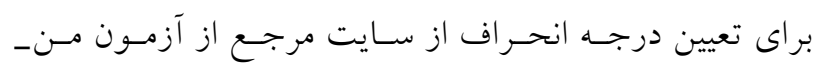

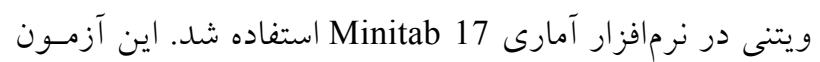
غيريارامتريك براى تجزيه و تحليل شاخص هاى كيفى كـاربرد

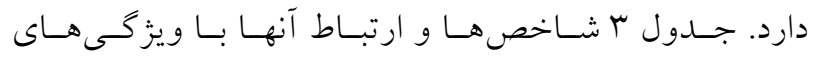
اكوسيستم بههمراه توضيح مختصـرى از شـاخصهــا را نشـان
كُندميان-بوته - علفى مىتواند باشد) ميان لكهها بهمعنسى انتقـال

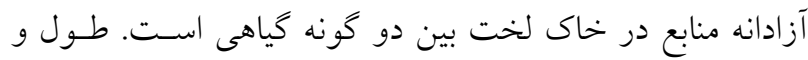

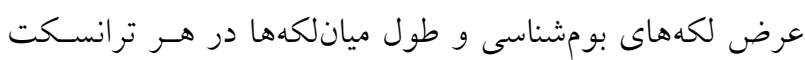

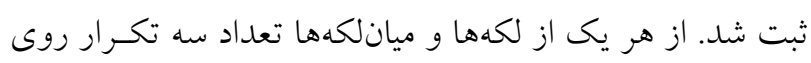

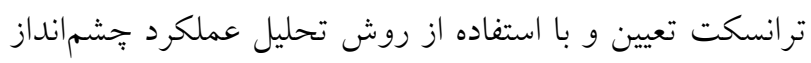

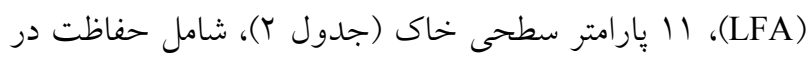

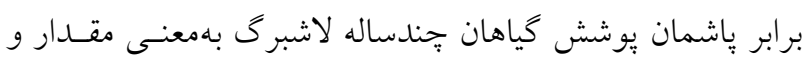

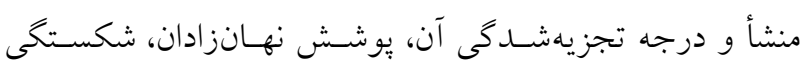

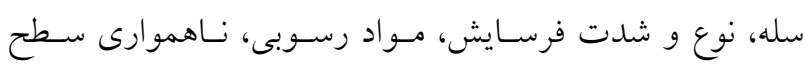

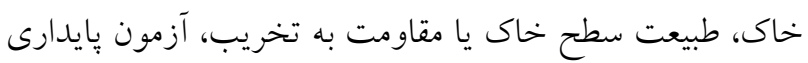
خاى و بافت خاك ارزيابى شد (11).

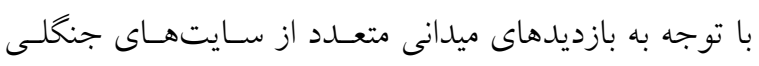

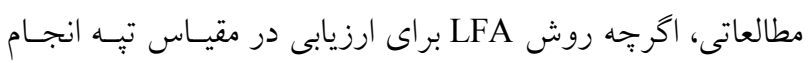
مىشود، اما اكر شرايط در قسمت اعظم حوضه تقريباً يكسان باشد،

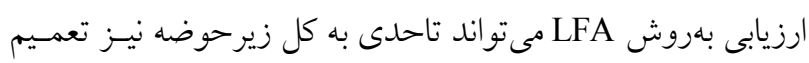

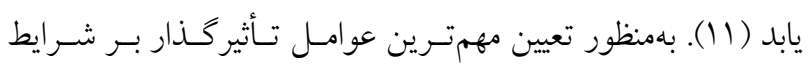

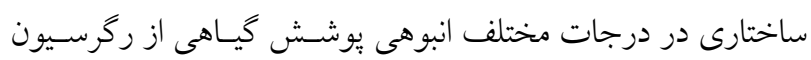

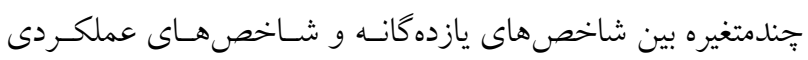

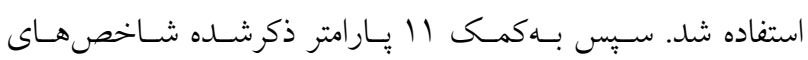

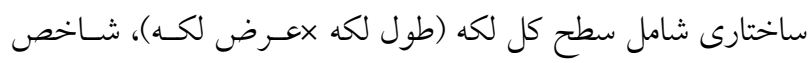

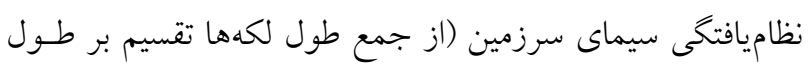

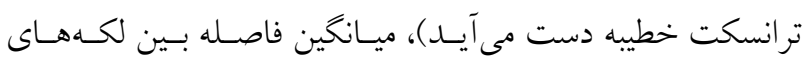

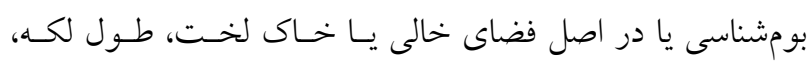

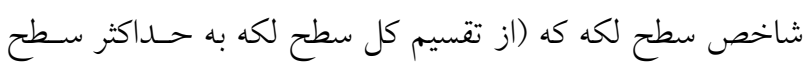

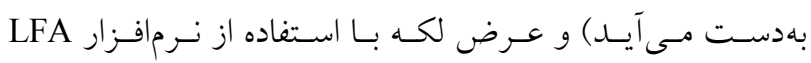

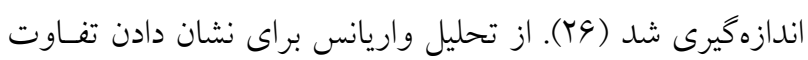

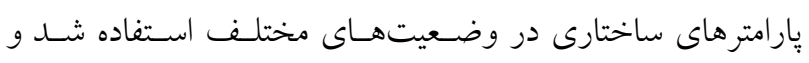

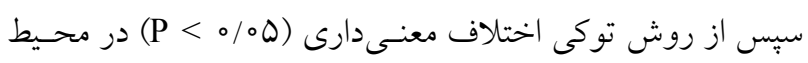
Minatab 17

اندازهيرى عملكرد بهروش LFA

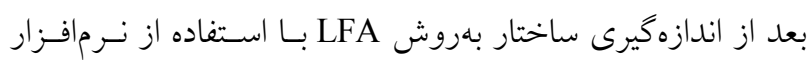
روش تجزيه و تحليل عملكرد جشـــانــاز، بارامترهـاى عملكـرد 


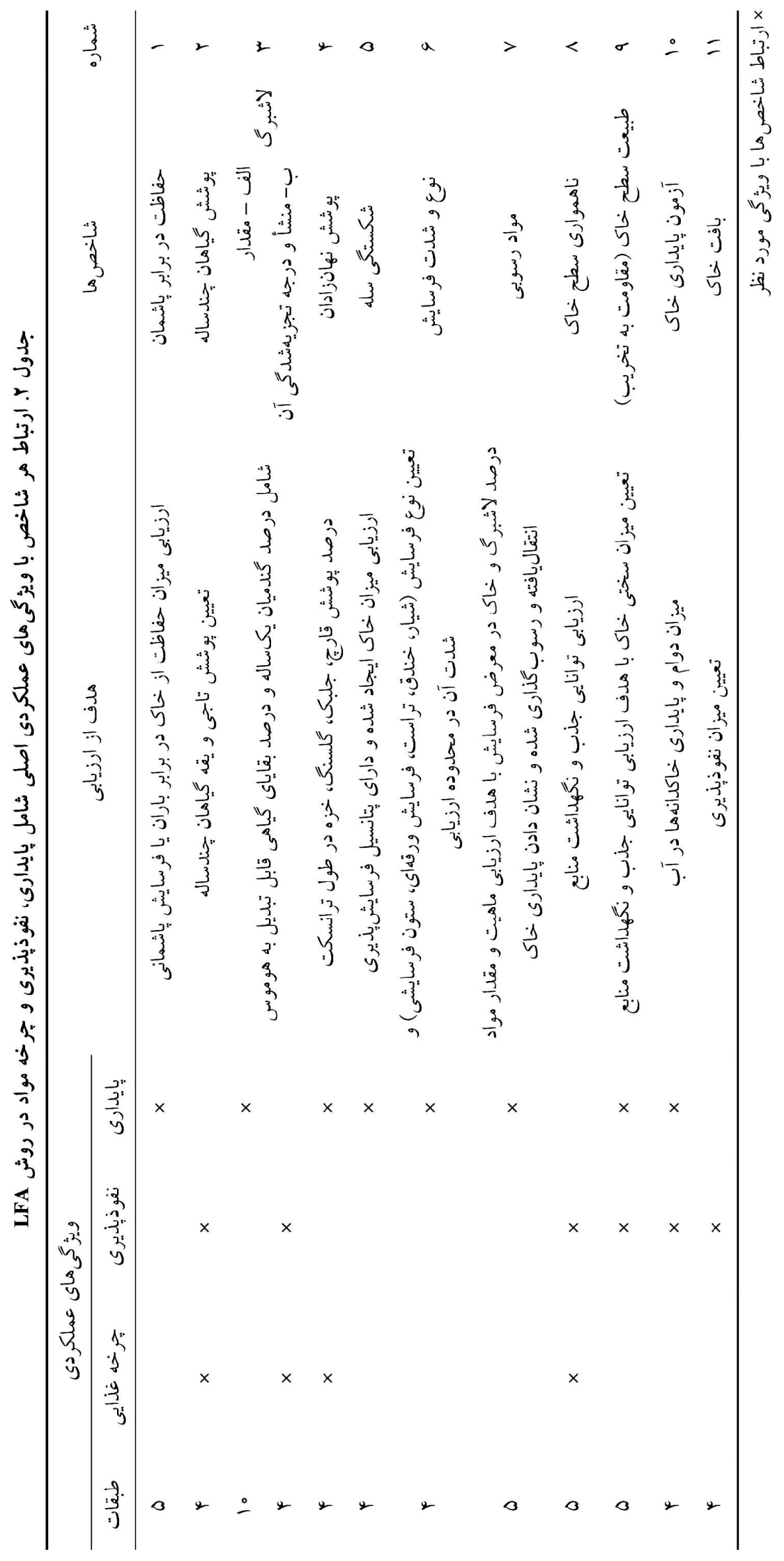




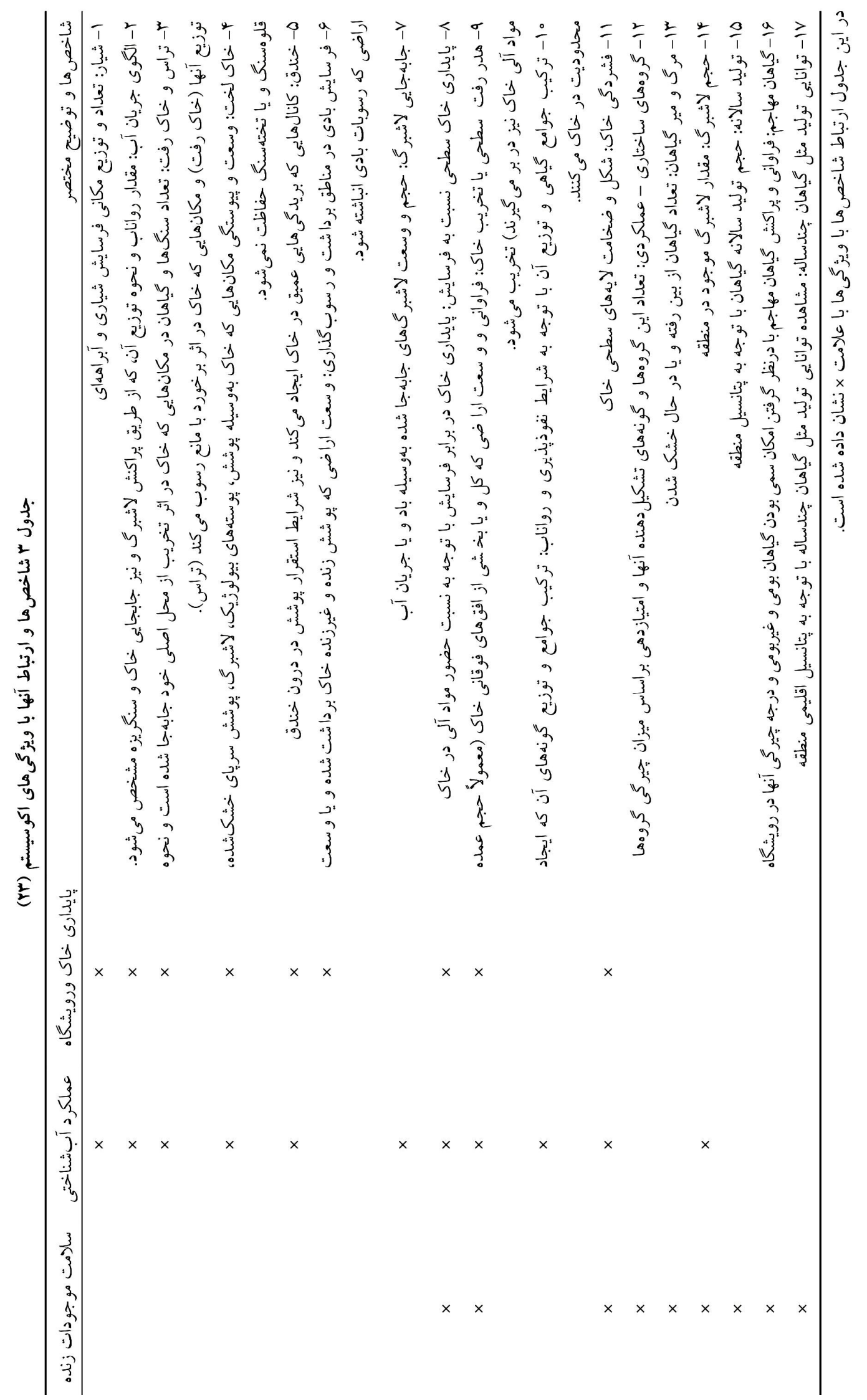


مجاورت بهدست مى آيد و انترويى مكانى بـهـهورت شـبكههـاى

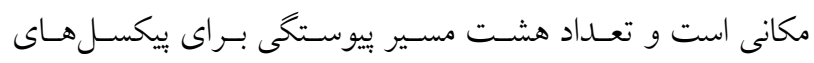

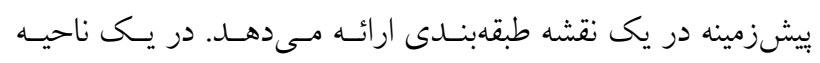

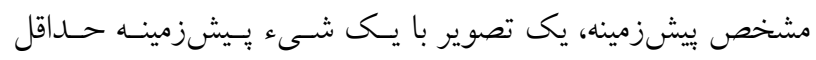

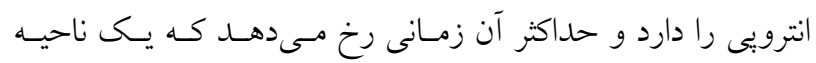
مشخص به حداكثر تعداد حالتهاى ممكن تجزيه و بر اكنده شـود. اين دو محدوده حداقل و حداكثر انتروبى را تعيين مى كنند.

\section{بيوستخى}

با استفاده از رويكرد يُنجره متحرك و بر اسـاس مجـاورت سـلول-

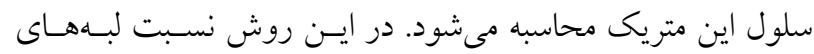
اثياء يِيشزمينه و تعداد كل لبههاى بين ييكسل ها ارزيابى مسى فــود.

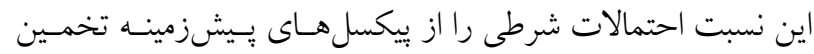

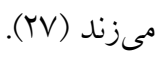

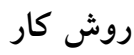
در اين روش كاربرى اراضى بـهـعنوان يـك نقشـه دو كانـه در سـهـ

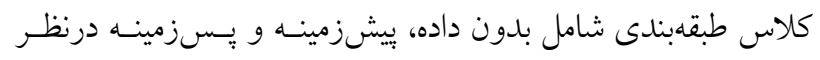

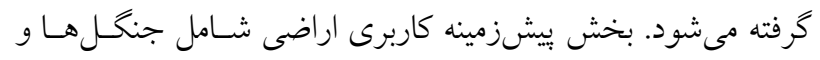

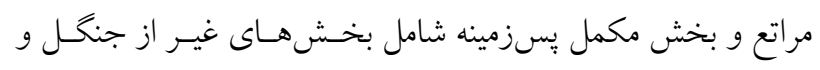

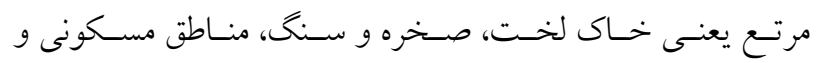

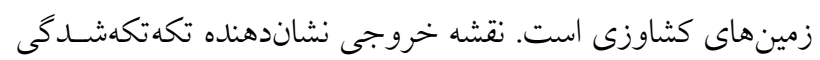

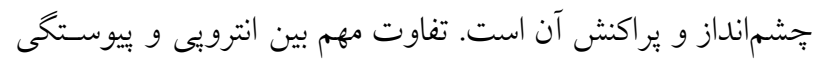
اين است كه انترويى به ارزيابى همزمان اشياء بيشزمينه و بس بسزمينه

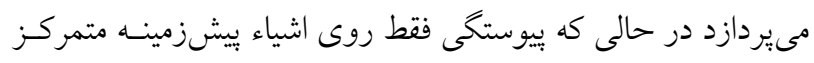

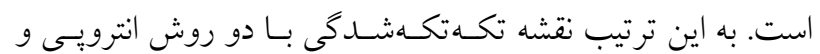

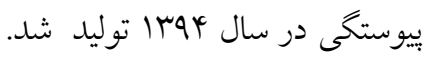

\section{نتايج و بحث}

نتايج شاخص هاى ساختارى و عملكردى در روش LFA

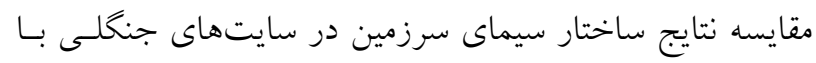

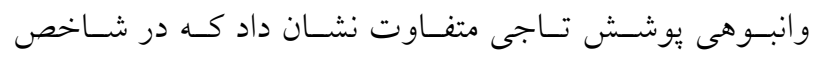

تجزيه و تحليل تفكيسكشـدگى سـيماى سـرزمين بـهروش

انترويى و بيوستخى (YV)

بعد از اندازهيرىها و ارزيابىهاى زمينى كه منجر به ارئه ائه نتايج

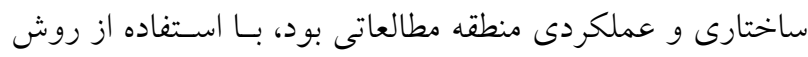

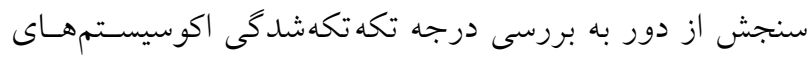

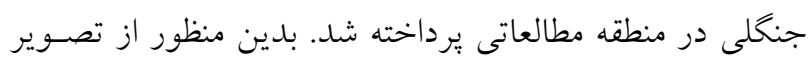

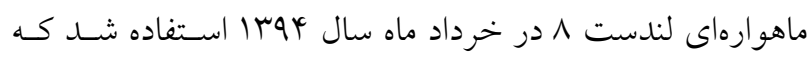

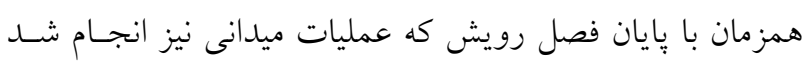

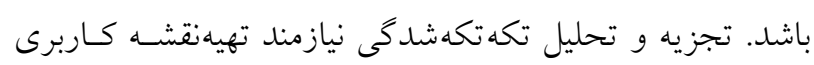

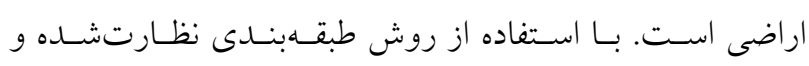

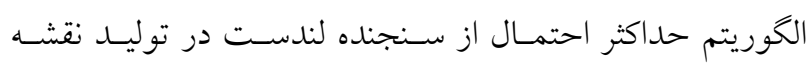

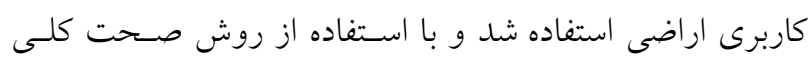

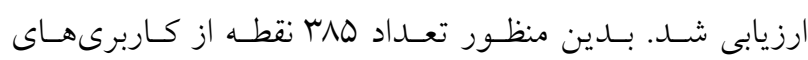

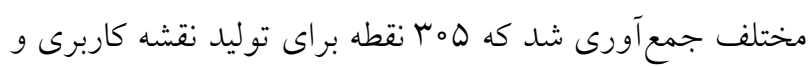
م1 نقطه بهمنظور ارزيابى صحت كلى نقشه توليدى استفاده شد.

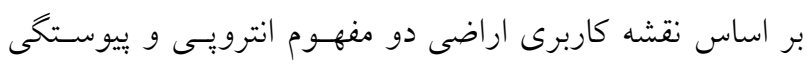

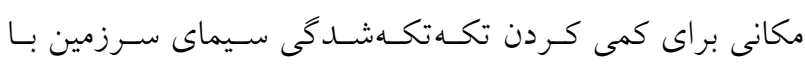
استفاده از Guidos2.6 استفاده شد (TV).

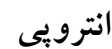
بر اساس مفهوم كلاسيك شانون (194N)، انترويى انترويى در اين روش

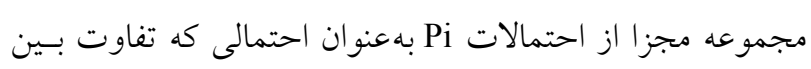

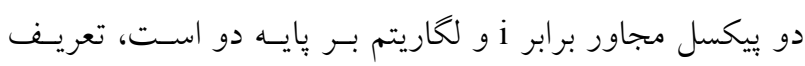

$\mathrm{H}=\sum_{\mathrm{i}} \mathrm{P}_{\mathrm{i}} \log \left(\mathrm{P}_{\mathrm{i}}\right)$

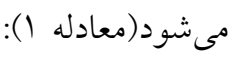

اين تئورى در زمينهاى مختلفى استفاده شده است و نكته مهـم

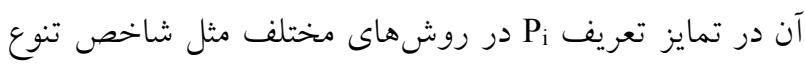
شانون است. در مفهوم اوليه Pi به درصد كـلاس هــاى كونـه در يكى نقشه طبقدبندى برمى گردد. در اين روش تفاوت بين ارزش سلولها در هشت جهت است كه ارزش همان مقـادير i استـا

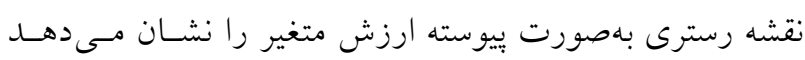

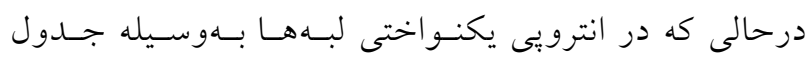


كاهش ميزان توليد و حجم لاشبرى خواهد شد.

شاخصهاى عملكرد در وضعيتهاى مختلف

مقايسه عمكرد براى شاخصهاى بايدارى خاك، نقوذيـذيرى و

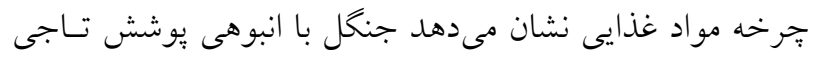

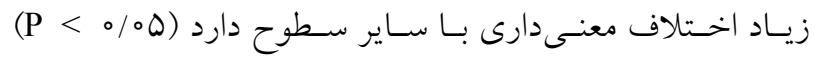

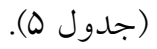

معنى دار بودن شاخص بايدارى در سايتهاى جنگلى با انبوهى

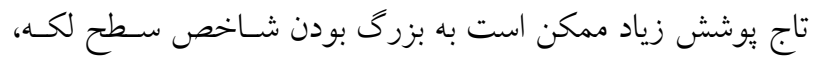

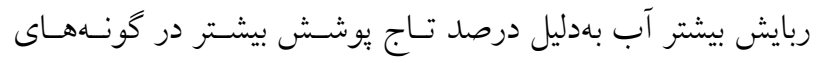

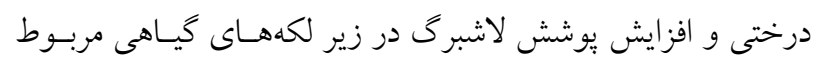

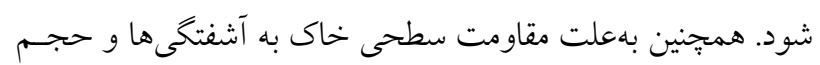

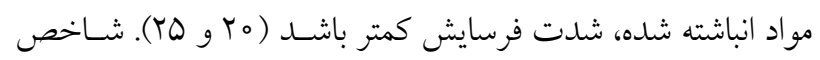
نفوذيذيرى در جنگكل با انبوهى متوسط و كم يوشش تاجى تفـاوت

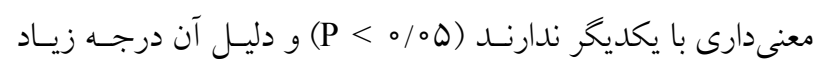

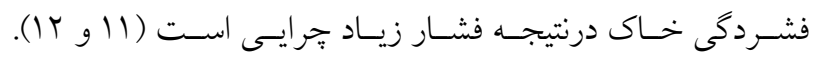

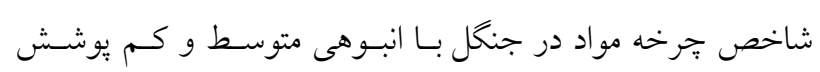

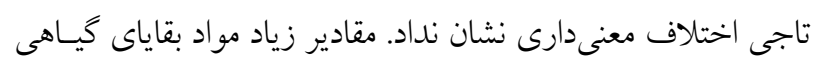

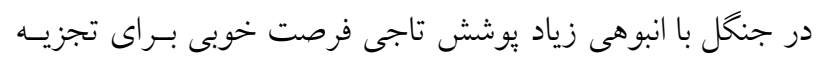

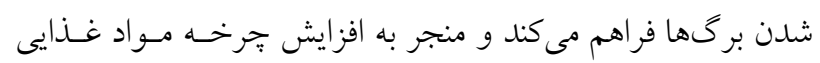

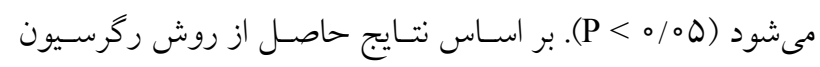

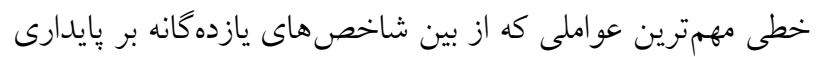

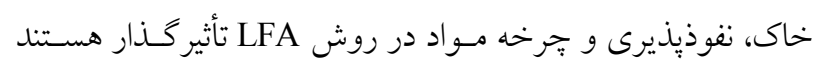
مدل ارائه شده در (جدول 9) هستند.

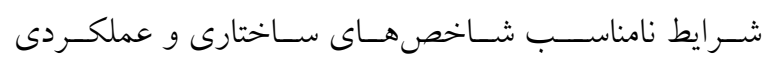

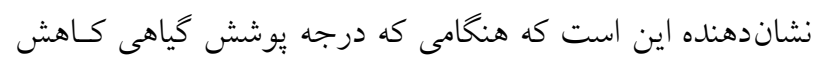

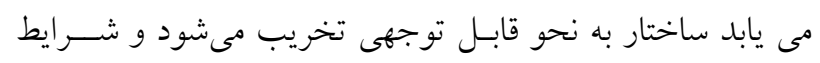

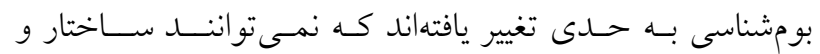

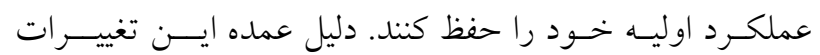
سـاختارى و عملكـــى به نوع مديريت اعمال شده در اين منـاطق

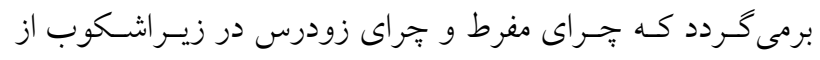

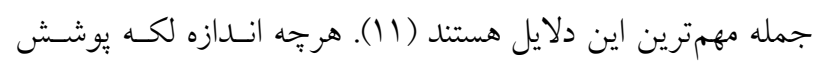

نظـاميـافتخى سـيماى سـرزمين و سـطح كـل لكـه ميـانخين شاخص هاى مورد بررسى بـا يكـديكر تفـاوت معنسى دارى دارد

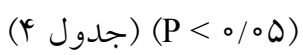

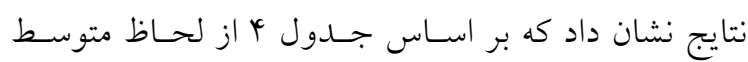

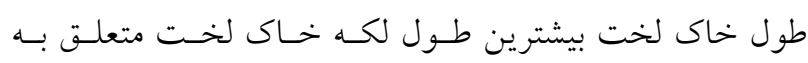
جنگل با درجه انبوهى كم يوشش تاجى كه ها متر است و ايسن

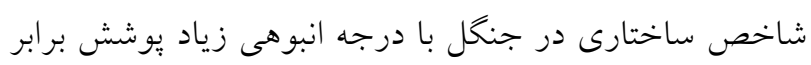

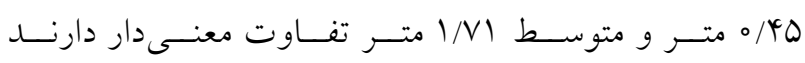

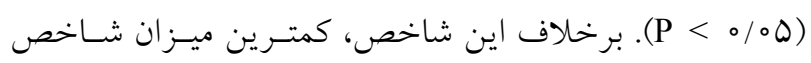

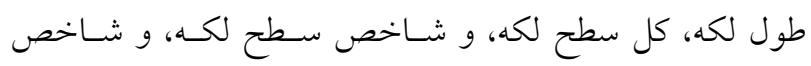

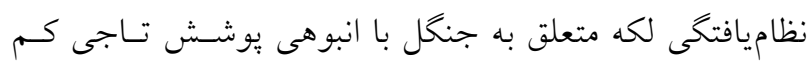

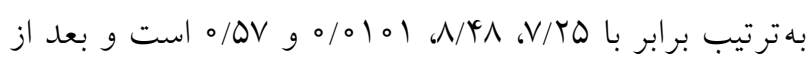

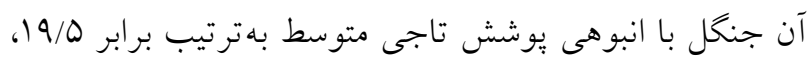

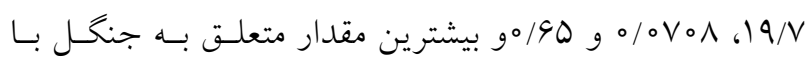

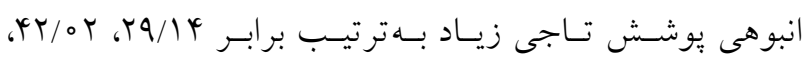

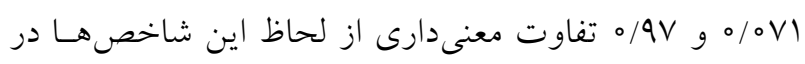

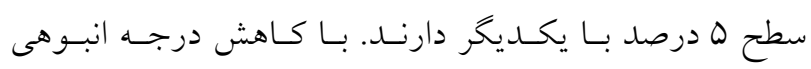
يوشش تاجى، شاخصهاى ساختارى شرايط نامناسبترى درى بيدا

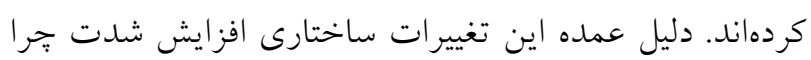
در زير اشكوب درختى، افزايش درصد تركيب كياهان يكساله

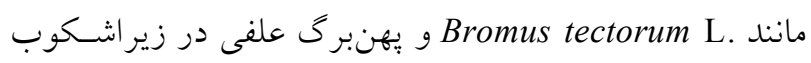

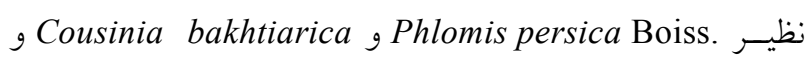
افزايش درصد خاك لخت است. اما در انبوهى يوشـش تـاجى

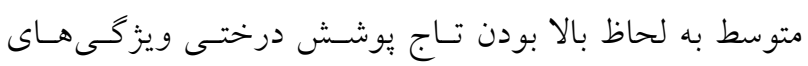

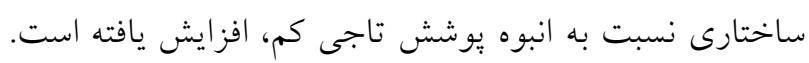

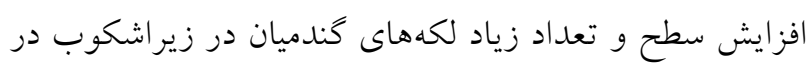

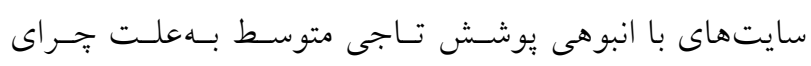

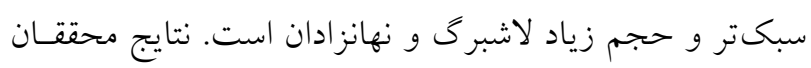

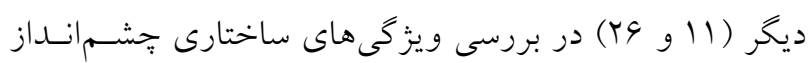

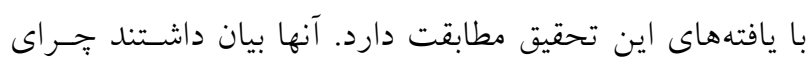

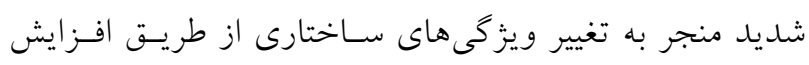

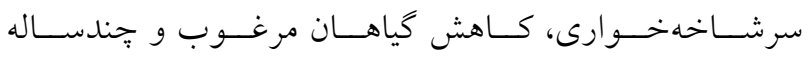

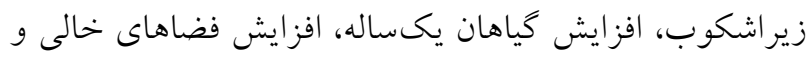


جدول Fأ. شاخصهاى ساختارى مورد بررسى در روش

\begin{tabular}{|c|c|c|c|c|c|c|}
\hline TA & IPA & PL & LOI & TAI & BSA & جنگً با انبوهى تاج بوشش \\
\hline$\varphi r / \circ \pm Y / \mu^{a}$ & $\circ / \circ \Delta \pm \circ / \circ \varphi b$ & $r q / 1 \pm \Delta / q^{a}$ & $\circ / 9 V \pm 0 / 011^{a}$ & $\circ / \circ V \pm 0 / 01 Y^{q a}$ & $\circ / \mathfrak{c} \pm \circ / \circ \circ /^{c}$ & زياد \\
\hline $19 / \mathrm{N} \pm 1 / \mathrm{rb}^{\mathrm{b}}$ & $l / I V \pm \circ / \mu^{\mathrm{wb}}$ & $19 / 0 \pm r / r^{b}$ & $0 / 90 \pm 0 / 0 Y y^{b}$ & $\circ / \circ V \pm \circ / \circ \Delta q^{a}$ & $1 / N \pm \circ / \circ \circ r^{\mathrm{b}}$ & متوسط \\
\hline$\Lambda /{ }^{c} \Lambda \pm 1 / V^{c}$ & $10 / 0 \pm 0 / 01^{a}$ & $V / \Gamma_{\circ} \pm 1 / \mu^{c}$ & $\circ / \Delta V \pm 0 / 019 b$ & $0 / 01 \pm 0 / 01 k^{c b}$ & $Q / \circ \pm \circ / / k 4 a$ & كم \\
\hline
\end{tabular}

TA سطح كل لكه، IPA: ميانخين فاصله لكههاى بومشناسى، PL: طول لكه، LOI: شاخص نظام يافتكى سيماى سرزمين، TAI: شاخص سطح لكه، BSA متوسط طول لكه خاى لخت. حروف abc در هر ستون نشاندهنده تفاوت معنىدار در سطح ه درصد بين خروهها است.

جدول ه. شاخصهاى عملكردى مورد بررسى در روش LFA

\begin{tabular}{|c|c|c|c|}
\hline $\mathrm{NC}$ & IFL & SS & جنگل با انبوهى تاج بوشش \\
\hline$\Delta \vee / q \pm \Lambda / q^{a}$ & $\Delta \vee / \Gamma^{\prime} \pm / \Delta^{\mathrm{a}}$ & $V Y / \uparrow \pm \Lambda / \varphi^{a}$ & زياد \\
\hline$Y Y / N \pm Q / q^{b}$ & $r y / 9 \pm 9 / q^{a b}$ & $\varphi \circ / \Lambda \pm r / \Gamma^{b}$ & متوسط \\
\hline$r \mu / V \pm 9 / \mu^{b}$ & $\Upsilon \wedge / \Lambda \pm Y^{\top} / \Upsilon^{b}$ & 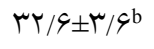 & 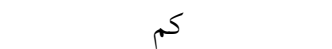 \\
\hline
\end{tabular}

SS

جدول 9. رگرسيون بين شاخصهاى عملكردى روش LFA و پارامترهاى يازده گانه مؤثر بر آنها

\begin{tabular}{|c|c|}
\hline مل مل ركرسيون & ضريب تبيين (درصد) \\
\hline Stability $=12.50+5.168 \mathrm{LC}+5.757 \mathrm{ETS}+2.278 \mathrm{DM}+4.091 \mathrm{SRD} .-3.96 \mathrm{ST}$ & $9 \circ$ \\
\hline Infiltration $=0.00070+1.75462 \mathrm{PCC}+1.75399 \mathrm{LCOI} .+1.75578 \mathrm{SSR}+3.50694 \mathrm{ST}+1.754 \mathrm{SRD}$ & 94 \\
\hline Nutrient $=5.84+3.422 \mathrm{LCOI}+2.326 \mathrm{CC}$ & $\wedge \Delta$ \\
\hline
\end{tabular}

لاشبرى نقش مهمى در بهبـود حاصسلخيزى و سـاختمان سـطح خاك ايفا مى كند (1) (1).

\section{نتايج شاخص هاى سلامت}

نتايج حاصل از مشاهدات و اندازهيرى شاخص هاى منطقـه نشـان داد از نظر شيارها و الخـوى جريـان آب در منطقـه وضـعيت نسـبتاً مطلوبى دارد. سنخ و سنخريزه به ميزان كـم و عسدم وجـود خـاك لخت ، آثار تجمـع رسـوبات بـهــورت براكنـده در يـاى گياهـان بوتهاى، قرار كرفتن پيايدارى سطحى خاك نسـبت بـه فرسـايش در

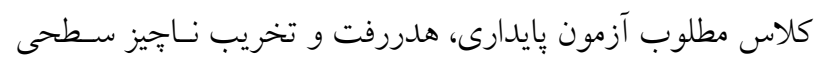

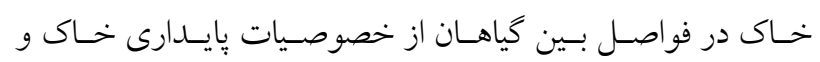
رويشخاه در اين سايت است. تركيـب جوامـع كيـاهى و توزيـع
كياهى افزايش يابد تسخير منابع هم بيشتر مسىشود (TQ). افـزايش خاى لخت در سايتهاى جنگلى با انبوهى بوشش تاجى كم سبب

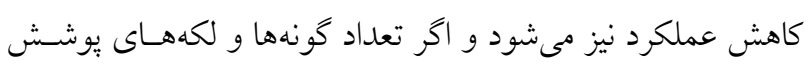
كَاهى در منطقـه مرجـع كـاهش يابــ نشـانكر تخريسب و كـاهش شرايط سلامت آن منطقه است. جراى شديد سبب كاهش كيفيت و كميت بوشش كياهى و افزايش ميزان خاك لخت شــ كـه افـزايش رواناب در اثر كاهش تـراكم يوشـش كيـاهى و لاشـبرى را منجـر

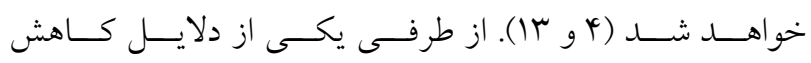
شاخصهاى عملكرد در سايت جنخلى با انبوهى يوشش تـاجى كم مىتواند از بين رفتن نهانزادان آوندى در اين سايتها باشـــ. افزايش بوسته ميكروبيوتيك در خاك، ساختمان و ويزگىىهـاى فيزيكى و شيميايى خاى را بهبود بخشيده و عـاوه بــر افـزايش 


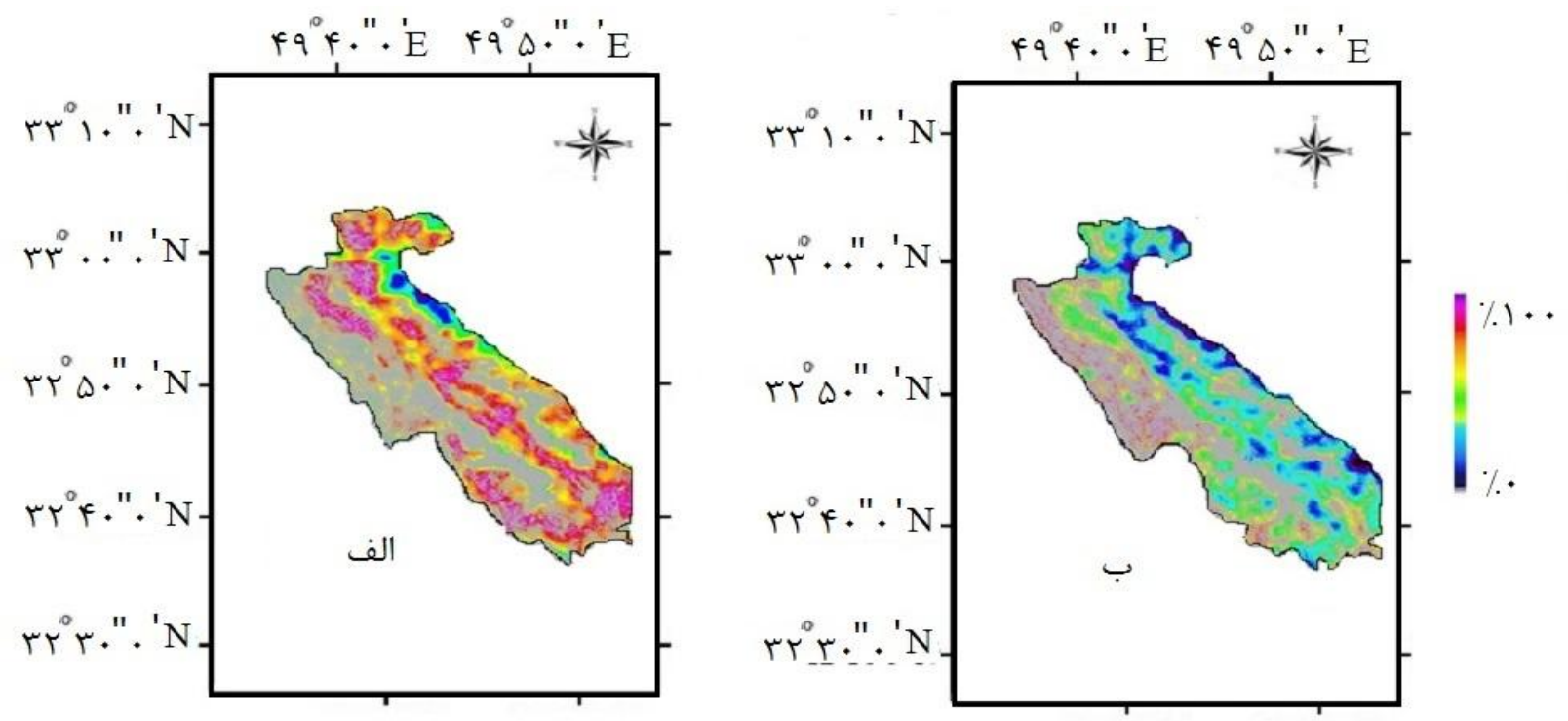

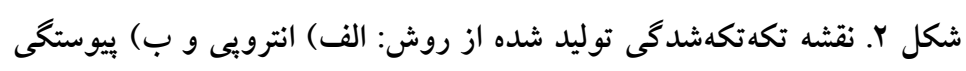

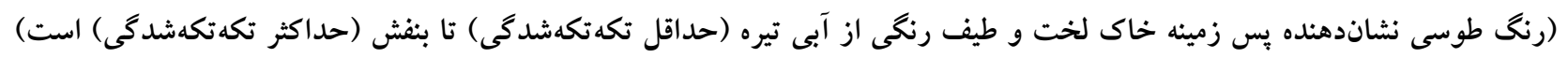
(رنخى در نسخه الكترونيكى)

عملكردى و تعداد كونهها در مقايسه با سايت مرجع كاهش يافتـه و

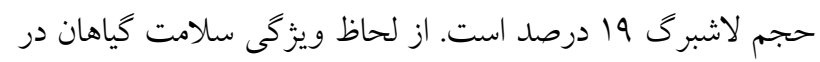

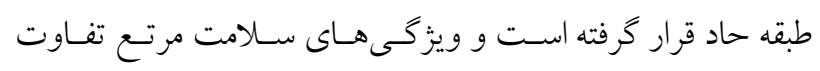

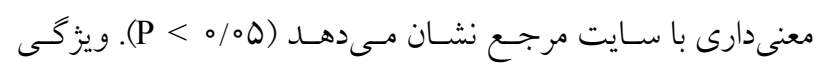

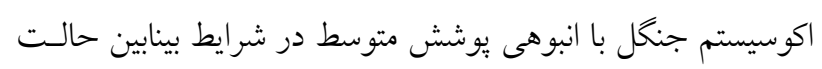

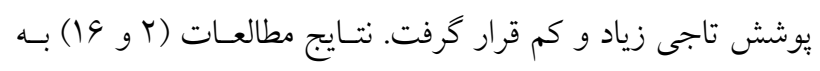
اهميت اين شاخصها در ارزيابى اكوسيستم اشاره داشته است.

\section{بررسى آثار تكه تكهشدگى}

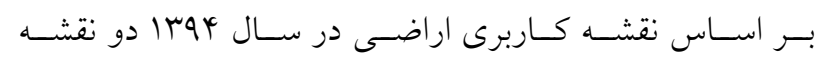

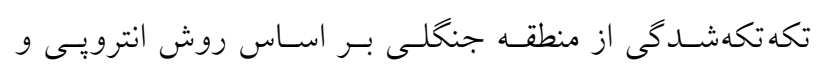

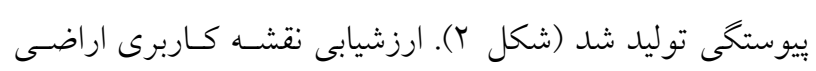

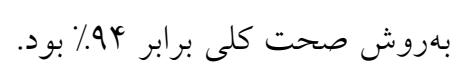

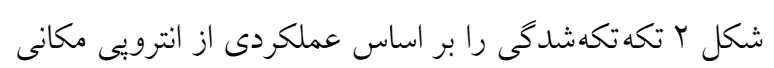

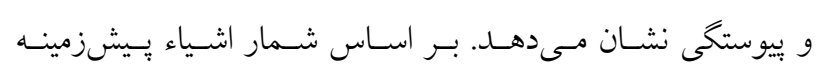

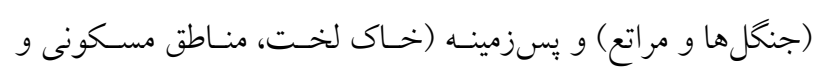

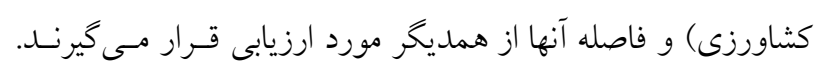

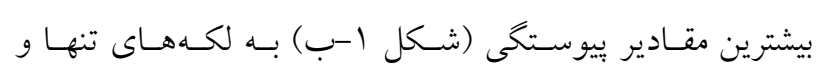

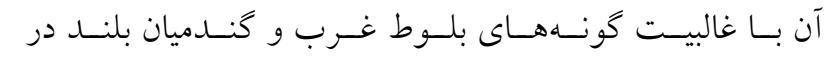
زيراشكوب آنها از لحاظ درصد تركيب و نقش مهم و تاثير گذار بهار

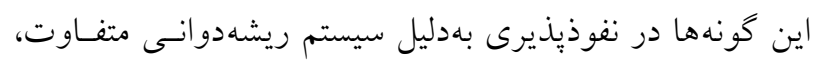

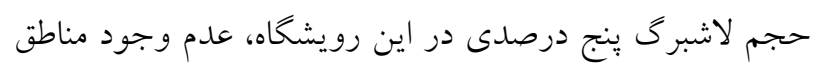

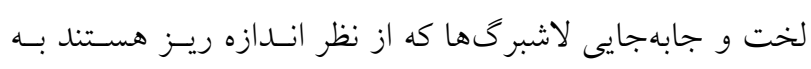

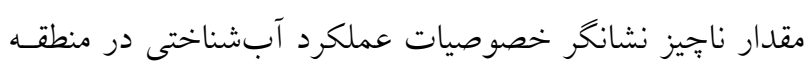

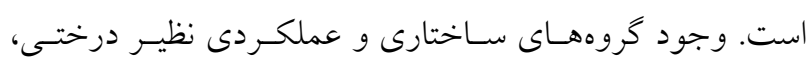

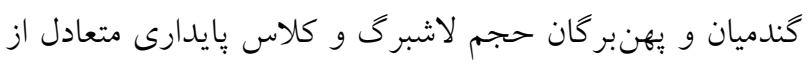
ويزگى هاى سلامت كياهان در اين رويشخاه است.

$$
\text { جنگل با انبوهى كم يوشش تاجى }
$$

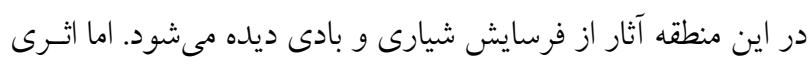

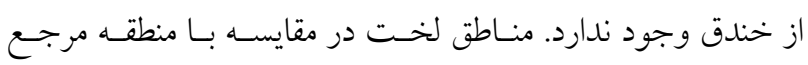

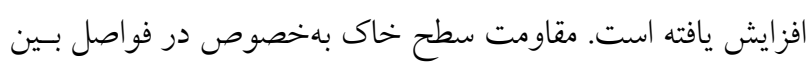

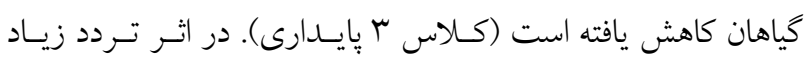

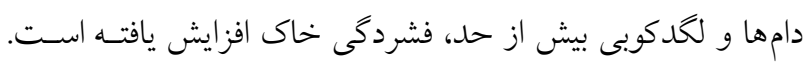

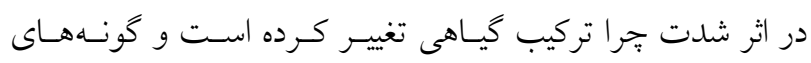

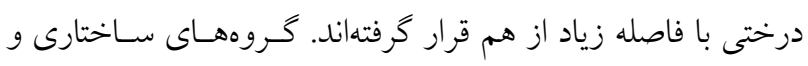




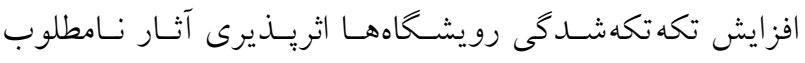

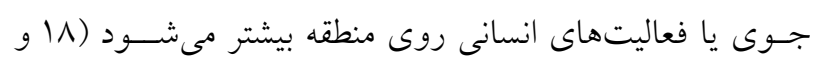
19) و اين وضعيت روى عملكرد است به نحسوى كـه بـهـدنبـال

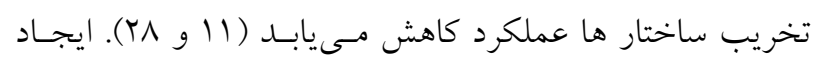

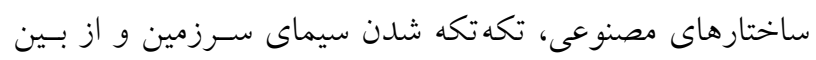

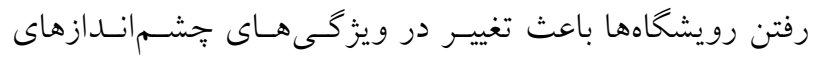

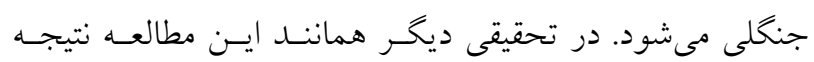

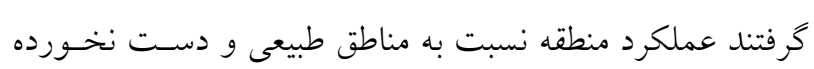

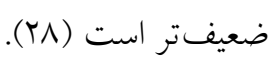

\section{نتيجه گيرى}

در سالهاى اخيـر فشـار شـــيد و زودرس منجـر بـه تغييـرات

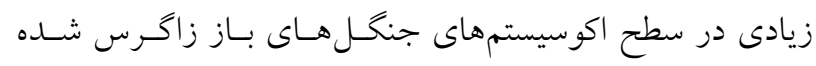

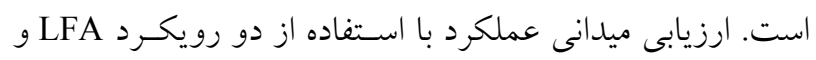

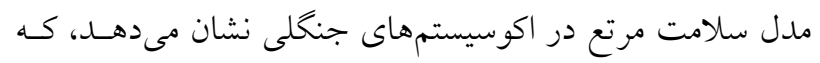

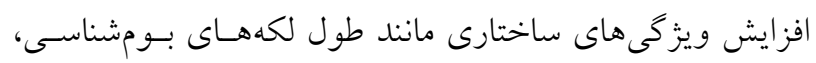

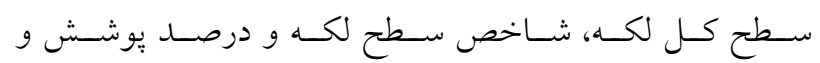

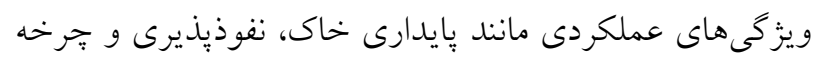

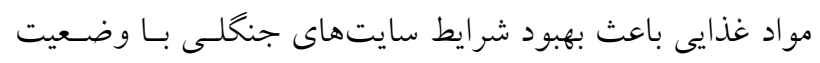

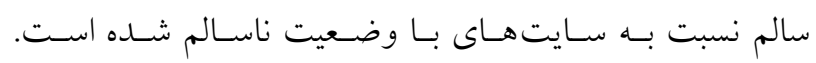

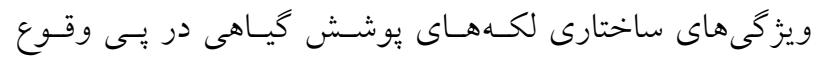

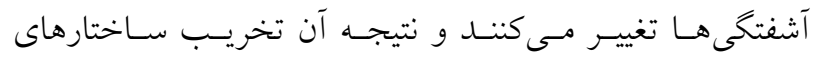

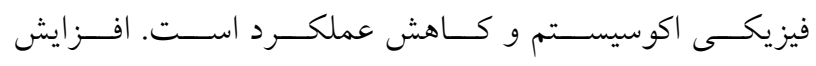

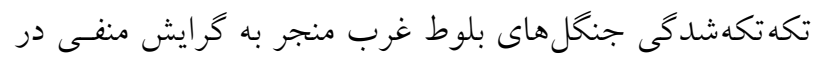

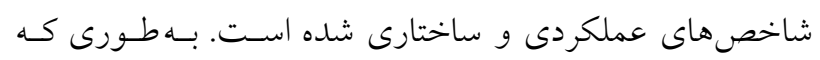

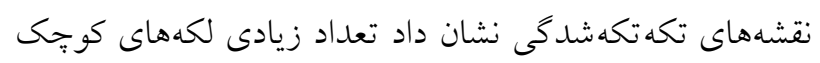

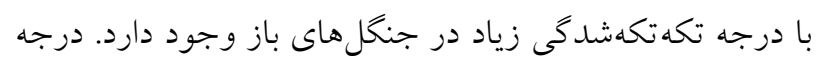

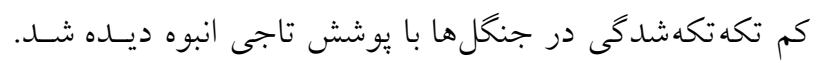

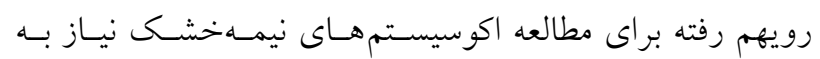

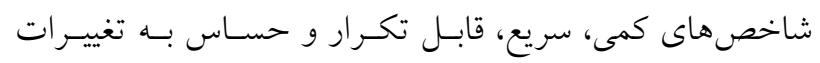

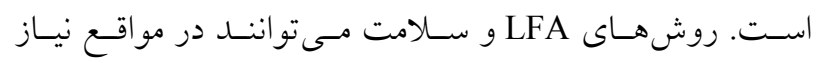

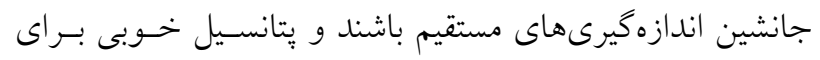

كوجــ مربـوط اسـت. بــر اسـاس ايسن رويكـرد، مقــادير كـم

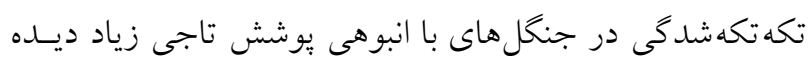

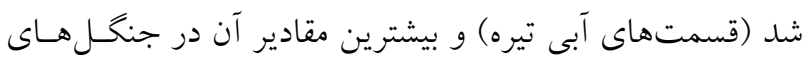

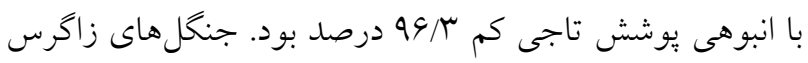

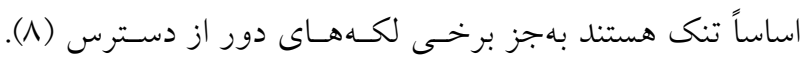

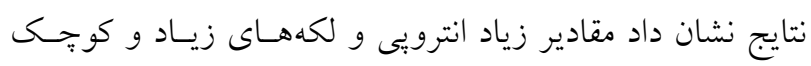
كياهى در بخش جنشلى است.

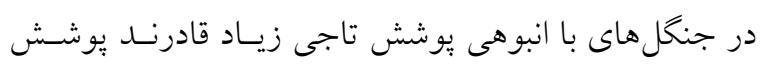

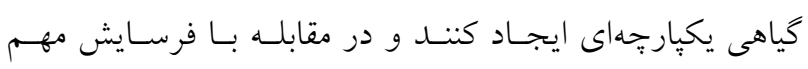

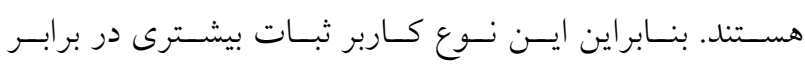

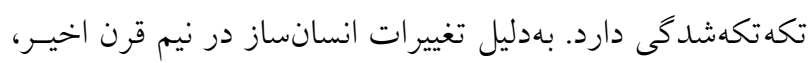
ارتباطات بين لكههاى بومشناسى كاهش يافتـه و در كـل منطقـهـ

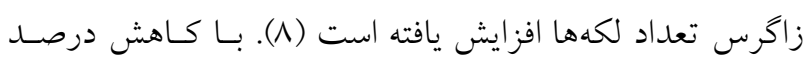
يوشش كياهى خاك بدون محافظ مى ماند و در خطر فرسـايش

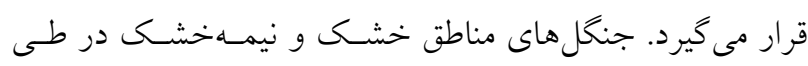

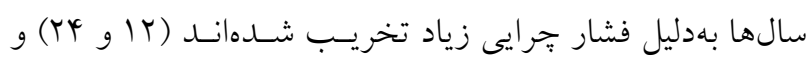

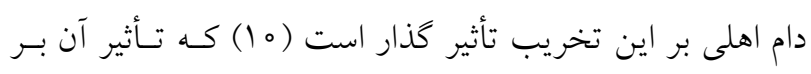

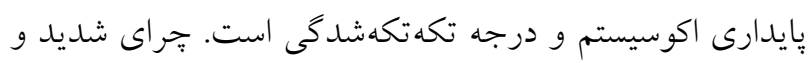

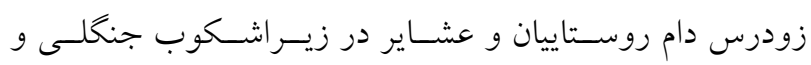

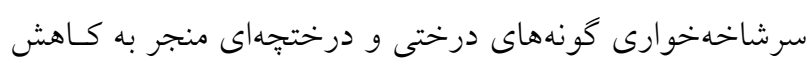

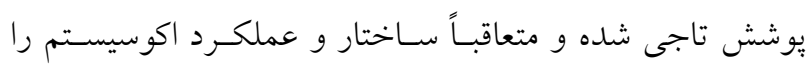

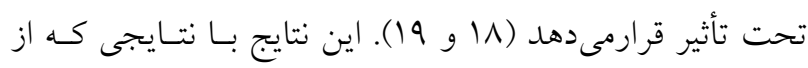
روش ميدانى (LFA) در تعيين ساختار سيماى سرزمين بهدست

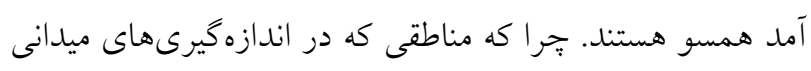

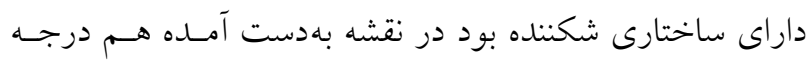

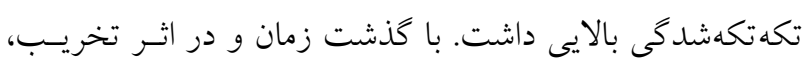

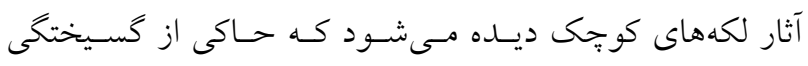

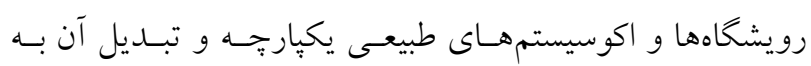

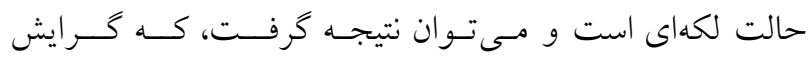

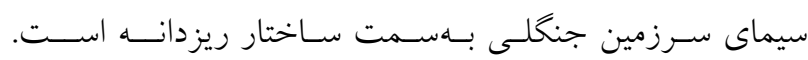

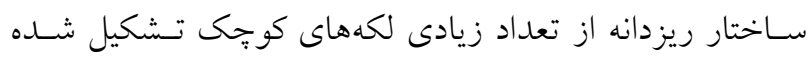

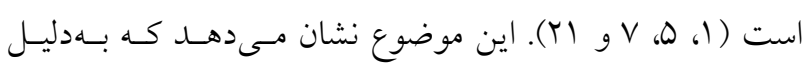




$$
\begin{aligned}
& \text { كمك به مديران در برنامهريزىهاى حفـاظتى و احيـايى فـراهم نتايج اين روش و روشهاى سنجش از دور مىتواند زمينهسـاز } \\
& \text { كنند. اين روش ها مىتوانند براى اولويتبنـدى منـاطق تخريسب توليد نتايج قابل اعتمادى براى اهداف مديريتى باشد. } \\
& \text { شده استفاده شوند و كزينههاى مـديريتى فـراهم كنــــ. تركيـب }
\end{aligned}
$$

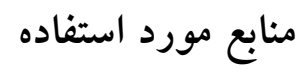

1. Almeida, D., J. Rocha, C. Neto and P. Arsénio. 2016. Landscape metrics applied to formerly reclaimed saltmarshes: A tool to evaluate ecosystem services? Estuarine, Coastal and Shelf Science 181(Supplement C): 100-113.

2. Arzani, H. and M. Abedi. 2004. Effect of management on rangelands health attribute and its ecological indicator. Rangeland and desert 13(2): 145-161 (In Farsi).

3. De Martonne, E. 1926. Une Nouvelle fonction climatologique: l'indice d'aridité. Gauthier-Villars, Paris, 532 p.

4. Don, A., T. Scholten and E. D. Schulze. 2009. Conversion of cropland into grassland: Implications for soil organiccarbon stocks in two soils with different texture. Plant Nutrition Soil Science 172: 53-62.

5. Eigenbrod, F. 2016. Redefining landscape structure for ecosystem services. Current Landscape Ecology Reports https://doi.org/10.1007/s40823-016-0010-0.

6. Evans, R. A. and R. M. Love.1957. The Step-point method of sampling-A practical tool in range research. Journals at the University of Arizona 10: 5-15.

7. Forman, R. 1995. Land Mosaics: The Ecology of Landscapes and Region. Cambridge University press, USA, 656 p.

8. Henareh Khalyani, A. and A. L. Mayer. 2013. Spatial and temporal deforestation dynamics of Zagros forests (Iran) from 1972 to 2009. Landscape and Urban Planning 117 (Supplement C), S. 1-12, DOI: 10.1016/j.landurbplan.2013.04.014.

9. Heshmati, Gh., P. Karami and M. Amirkhani. 2006. Evaluating rangeland ecosystem potentioal in Inche borun region, Golestan. Journal of Agriculture and Natural Resources Science 4(1): 1-9 (In Farsi).

10. Illius, A. W. and T. G. O’Connor. 1999. On the relevance of nonequilibrium concepts to arid and semiarid grazing systems. Ecological Applications 9: 798-813, DOI: 10.1890/1051-0761(1999)009[0798: OTRONC] 2.0.CO; 2.

11. Jafari F., R. Jafari and H. Bashari. 2017. Assessing the performance of remotely sensed landscape function indices in semi-arid rangelands of Iran. The Rangeland Journal 39: 253-262.

12. Jafari, R., H. Bashari and M. Tarkesh. 2017. Discriminating and monitoring rangeland condition classes with MODIS NDVI and EVI indices in Iranian arid and semi-arid lands. Arid Land Research and Management 31(1), S. 94-110, DOI: 10.1080/15324982.2016.1224955.

13. Krümmelbein, J., S. Peth, Y. Zhao and R. Horn. 2009. Grazing-induced alterations of soil hydraulic properties and functions in Inner Mongolia,PR China. Plant Nutrition Soil Science 172: 769-776.

14. Li, X. R., H. L. Xiao, J. G. Zhang and X. P. Wang. 2004. Long-term ecosystem effects of sand-binding vegetation in the Tengger Desert, northern China. Restoration Ecology 12: 376-390.

15. McGarigal, K., S. Cushman, M. Neel and E. Ene. 2002. FRAGSTATS v3: Spatial Pattern Analysis Program for Categorical Maps. Computer software program produced by the authors at the University of Massachusetts, Amherst. Available at the following web site: http://www.umass.edu/landeco/research/fragstats/fragstats.html.

16. Molaeinasab, A., H. Bashari, M. Tarkesh and M. R. Mosaddeghi. 2018. Soil surface quality assessment in rangeland ecosystems with different protection levels, central Iran. CATENA 171: 72-82, https://doi.org/10.1016/j.catena.2018.07.004.

17. Mollaei, M. 2010. Study of LFA effectiveness for evaluating stability and organic matter content in some rangeland sites. MSc thesis, Isfahan University of Technology, Iran.

18. Naghipour, A. A., H. Bashari, S. J. Khajeddin, P. Tahmasebi and M. Iravani. 2016. Effects of smoke, ash and heat shock on seed germination of seven species from Central Zagros rangelands in the semi-arid region of Iran. African Journal of Range \& Forage Science 33: 37-71, https://doi.org/10.2989/10220119.2015.1119194.

19. Naghipour, A., S. J. Khajeddin, H. Bashari, P. Tahmasebi and M. Iravani. 2014. Effects of fire Products on the Seed Germination of the Three Dominant Species from Astragalus Genus in Semi-Steppe Rangelands of Central Zagros, Iran. Iranian Journal of Applied Ecology 3(9): 71-80, http://ijae.iut.ac.ir/article-1-567-en.html. (In Farsi).

20. O'Sullivan, L., R. E. Creamer, R. Fealy, G. Lanigan, I. Simo, O. Fenton, J.Carfrae and R. P. O. Schulte. 2015. Functional land management for managing soil functions: A case-study of the trade-off between primary 
productivity and carbon storage in response to the intervention of drainage systems in Ireland. Land Use Policy 47: 42-54.

21. Plexida, S. G., A. I. Sfougaris, I. P. Ispikoudis and V. P. Papanastasis. 2014. Selecting landscape metrics as indicators of spatial heterogeneity-A comparison among Greek landscapes. International Journal of Applied Earth Observation and Geoinformation, https://doi.org/10.1016/j.jag.2013.05.001.

22. Popp, A., N. Blaum and F. Jeltsch. 2009. Ecohydrological feedback mechanisms in arid rangelands: Simulating the impacts of topography and land use. Basic and Applied Ecology 10(4): 319-329.

23. Pyke, D. A., M. Pellant, P. Shaver and J. E. Herrick. 2001. Interpreting Indicators of Rangeland Health. National Science and Technology Center, Technical Reference, Denver, Colorado, USA, 136 p.

24. Thompson N. H., A. G. Kathleen J. S. Chris, J. A. Randall, B. B. Robin and P. K. Thornton. 2008. Fragmentation of rangelands: Implications for humans, animals, and landscapes. Global Environmental Change 18(4): 776-785, https://doi.org/10.1016/j.gloenvcha.2008.07.011.

25. Tongway, D. J. and A. Ludwig. 1990. Vegetation and soil patterning in semi-arid mulga lands of Eastern Australia. Journal of Ecology 15: 23-34.

26. Tongway, D. J. and N. Hindley. 2004. Landscape Function Analysis: Procedures for Monitoring and Assessing Landscape. CSIRO, Brisbane, Australia, $80 \mathrm{p}$.

27. Vogt, P. 2015. Quantifying landscape fragmentation. Institute of Landscape Ecology Slovak Academy of Sciences, S. 978-80-89325-27-6. http://www.uke.sav.sk.

28. Walt, L., S. S. Cilliers, K. Kellner, M. J. Du Toit and D. J. Tongway. 2015. To what extent does urbanization affect fragmented grassland functioning? Journal of Environmental Management 151(0): 517-530.

29. Website of forest and rangeland organization. 2018. http://frw.org.ir/00/Fa/StaticPages/Page.aspx?tid=1500. 


\title{
Spatial Analysis of Central Zagros Forest Fragmentations for Conservation and Restoration Purposes (A Case Study: Posht kuh Forests, Fereydoonshahr, Isfahan Province)
}

\author{
M. Safaei ${ }^{1}$, R. Jafari ${ }^{*}$ and H. Bashari ${ }^{1}$
}

(Received: Oct. 22-2018; Accepted: Jan. 12-2019)

\begin{abstract}
In the current study, conservation strategies were employed for the spatial analysis of forest fragmentation and field assessment approaches in a forest landscape of Central Zagros, in the western part of Isfahan province, Iran. Vegetation and soil properties were accordingly studied in 15 forest sites with various densities including dense, semi-sparse and sparse-forests with $839.2 \mathrm{~km}^{2}$. In the Landscape Function Analysis (LFA) method, 11soil surface indicators were assessed from each patch and inter-patch zones along the established transects to obtain three functional indices including soil-stability, infiltration and nutrient-cycling. In the health method, assessors rated 17 indicators to evaluate three functional attributes of ecosystems including soil and site-stability, biotic-integrity and hydrologic-function. Land use map of the study area was produced using Landsat OLI (2016) to measure the spatial distribution of fragmentation. The results of LFA showed that the stability and nutrient-cycling indices of the dense-forest sites were 72.4 and $57.9 \%$, respectively, which were significantly higher than those in other lands $(p<0.05)$. According to the health results, soil surface loss, invasive plants and soil surface resistance to erosion were the most important factors influencing the health of the sites. The values of normalized fragmentation in dense-forest and sparse-forest areas were $54 \%$ and $96.3 \%$, respectively. According to the obtained results, the combined field-based and remotely-sensed approaches applied in this research could be used to assess the functionality of Zagros forests.
\end{abstract}

Keywords: Ecosystem health, Landscape function analysis, Structural and functional indices.

1. Dept. of Natur. Resour., Isf. Univ. of Technol., Isfahan, Iran.
*: Corresponding Author, Email: reza.jafari@cc.iut.ac.ir 